\title{
Karakorum, the first capital of the Mongol world empire: an imperial city in a non-urban society
}

\author{
Jan Bemmann ${ }^{1}$ (D) Susanne Reichert ${ }^{1}$ (i) \\ Received: 29 August 2020 / Accepted: 28 October 2020 / Published online: 8 December 2020 \\ (C) The Author(s) 2020
}

\begin{abstract}
Cities within a steppe environment and in societies based on pastoral nomadism are an often overlooked theme in the anthropological literature. Yet, with Karakorum, the first capital of the Mongol Empire (AD 1206-1368), we have a supreme example of such a city in the central landscape of the Orkhon valley in Mongolia. In this paper, we ask, what is the city in the steppes? Taking Karakorum as our starting point and case of reference and to attain a better comprehension of the characteristics of urbanism in the steppe, we apply a list of urban attributes compiled by Michael E. Smith (2016) to provide a thick description of Karakorum. The discussion not only comprises comparisons to other contemporary sites in Russia and Mongolia, but also addresses in detail the question of city-hinterland relations as a fundamental necessity for the survival of the city in an antiurban environment. The analysis shows that during the Mongol period we can identify urbanism but no urbanization: there is no process of independent, natural growth of cities carried out by the population, but cities are "political" in the sense that they are deeply intertwined with the authority and have therefore much to tell about the relation between power and authority on the one hand and the ruled on the other.
\end{abstract}

Keywords Mongol empire $\cdot$ Urbanism $\cdot$ Imperial city $\cdot$ Urban planning $\cdot$ Nomads

\section{Introduction}

"The concept of 'city' is notoriously hard to define" (Childe 1950: 3). This initial statement by V. Gordon Childe in his seminal paper on the so-called Urban Revolution is all the more true if we look at urban settings within the steppe environment of eastern Asia. Comparative archaeological debates of urban settings (Cowgill 2004; Smith 2011) and handbooks on early cities (Marcus and Sabloff 2008b; Clark 2013; Yoffee 2015) more or less neglect the constructed centers of nomadic empires in the Eurasian Steppes. As far as we know there is no book, no special volume of a journal, no conference proceeding that focuses on urban sites in the Eastern Eurasian steppes. There are only a monograph with collected studies by Kyzlasov (2006) on permanent settlements and urban sites mainly in Tuva, a book by Tkachev (2009) on the history of Mongolian architecture, and an edited volume by Kradin

Jan Bemmann

jan.bemmann@uni-bonn.de

1 Department of Pre- and Early Historical Archaeology, Bonn University, Brühler Straße 7, 53119 Bonn, Germany
(2018) on urban sites in Mongolia, Transbaikalia, and the Russian Far East. The Eurasian Society and the University of Bern in 2016 hosted a conference on "Urban Culture in Central Asia." The proceedings of this conference, however, include only lectures about the former Soviet republics in Central Asia from the Bronze Age to the Qara Khanids (Baumer and Novák 2019).

There may be two explanations for this shortcoming. First, many scholars focus on the so-called ancient civilizations, which is an unsuitable term as it perpetuates the dichotomy between civilized and barbarians. Cities are, in the opinion of many scholars, strongly connected with the rise of early states. In his recent book, Killing Civilization, Justin Jennings not only explains why we should refrain from using this term but also why the two concepts of emerging statehood and urbanism need to be disentangled (Jennings 2016). A second reason lies within geopolitics of the twentieth century. The Eurasian steppe zone, which includes the former Soviet Union and its satellite states as well as parts of China, was inaccessible for researchers from Western industrial states for most part of the twentieth century.

The inaccessibility of the literature from these regions and the inability to perform field research led the scholarly 
community to miss out on valuable comparative case studies. One in particular, concerning the steppes of present-day Mongolia, offers a remarkable diversity of settlement types over time, and most of them were never reoccupied after their decline. There are residences, fortresses, large urban sites, linear fortification walls, walled enclosures, monasteries, and permanent settlements with pit houses. Many of them were already discovered at the end of the nineteenth century (Radloff 1892), and the Mongolian scholar and founding father of Mongolian archaeology, Kh. Pèrleee, listed more than 200 in a comprehensive study in 1961. These works, however, are of an empirical character, and questions concerning the why and how of urban foundations and the underlying societal implications are seldom addressed.

Taking the famous city of Karakorum (Fig. 1), the first capital of the Mongol World Empire, as a starting point, we ask, what is a city in the steppe? We test whether the theories and definitions developed for cities in sedentary societies, exemplified by Michael E. Smith (2011), are applicable to sites in pastoral nomadic societies. For the sake of clarity, we need to underline a necessary differentiation: urban, urbanism, and urbanization are not interchangeable terms but have specific semantic meanings (see Gaydarska 2017: 181-182; M. L. Smith 2003: 12-13). Within this paper, urbanism means the existence of large, fixed settlements with a wide variety of functions and social groups in a qualitative difference to the hinterland (with urban denoting this difference), while urbanization means the process of dispersing this way of life through society in a longer perspective, and sustainable growth and endurance of these cities irrespective of political, ecological, social, or other upheavals. Do the particular economic configurations of our working area command a different trajectory in urbanization as compared to urbanization in sedentary subsistence economies? Faced with the transient nature of Mongolian urbanism, can we talk about urbanization at all or should we rather refrain from using the term? To elucidate and explore such questions, we feel it first necessary to develop a better comprehension of the characteristics of urbanism in the steppe. Therefore, we apply a list of urban attributes compiled by Smith (2016) to provide a thick description of Karakorum (sensu Geertz 1973: 3-30). This description follows along structural characteristics. What we do not intend to do is write yet another outline of Karakorum's history based on the few written sources available in translation into western European languages (cf. Sagaster 1999; Barkmann 2002; Gießauf 2003; Hüttel 2004). We concentrate on Karakorum because compared to other sites in Mongolia, many studies and a variety of source

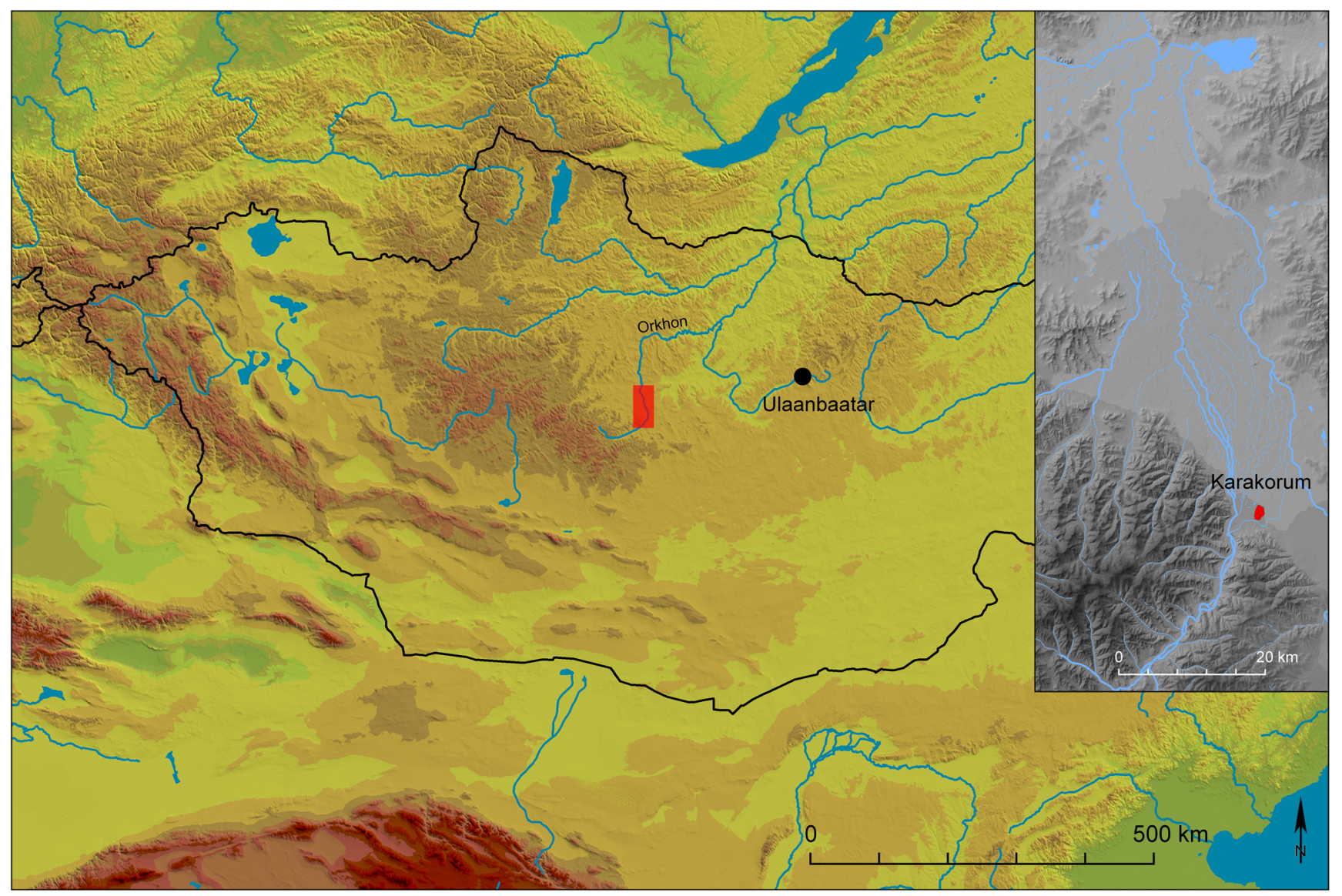

Fig. 1 Mongolia and the Orkhon Valley, inset showing Karakorum marked in red (graphic by Tobias Pfaff, Bonn) 
materials are available, including excavation reports and written sources, survey data, and very precise maps. The only other city with a similarly advanced state of research is Chin Tolgor̆, which is, however, of earlier date (Kradin 2011). This comparatively rich trove allows us to apply several methods from a variety of disciplines to describe these characteristics, ranging from archaeology, through history, and to urban planning. In the following, we will first lay out the theoretical and methodological foundation, after which we analyze Karakorum. Comparisons to contemporaneous sites contextualize Karakorum within the wider characteristics of Mongol period urbanism. Ensuing from this discussion, the nature of urbanism in the Mongolian steppes reveals further insights into power and authority since the emergence of these cities that is inherently linked to empire. Karakorum functions thus as a classic example of the "political city" as opposed to the "economic city" as discussed by Smith (2016). While the latter are "cities in which growth feeds on itself," the former's growth is mostly dependent on political or ritual impetuses (Smith 2016: 165).

\section{Theoretical framing: What is the city in the steppe?}

To start with, we should ask if Karakorum is a city at all. Does it comply with common criteria of urbanism (here in the meaning of being a city)? Since Childe published his trait list in 1950 there has been an ongoing debate over which criteria a site needs to fulfill in order to be ranked as a city (cf. Marcus and Sabloff 2008a: 12-20). Size, area, and high population density were commonly held as deciding factors (Wirth 1938), but theories of "low density urbanism" (Fletcher 2012) clearly show that there is no such thing as one category of population density for an urban site. Apart from our daily experience of cities as compact, nucleated aggregations of people, many modern cities and premodern cities are comparatively loosely settled (Fletcher 2012). Such demographic or sociological criteria are but only one way of defining cities.

Another angle to this task looks into the functions that settlements perform. Based on the seminal study by Walter Christaller (1933), functional criteria gained higher influence in historical geography. In this theory, the existence of specialized functions serves to identify central places, which supplied critical services for a hinterland with lower ranking places. Depending on the quantity and reach of functions of each site, a hierarchical settlement pattern can be reconstructed. Although the theoretical foundations of the model have long been refuted in geographical scholarship and Walter Christaller's entanglement with the Third Reich is widely known (e.g. Kegler 2015), this concept found adaptation in archaeological studies and is still being widely used (Gringmuth-Dallmer 1999; Müller 2012; Nakoinz 2012).
The ready adaptation in archaeology might be due to the charisma evoked by the terms "central place," "centrality," and "functions of settlement" popularized by Christaller: rather than applying the model with its problematic theoretical assumptions, archaeological studies merely refer to these concepts. At the same time, these terms - or rather the application thereof - often produce rather static glimpses of what must have been dynamic processes in the past.

Another critique one can put forward vis-à-vis functional definitions of cities stems from application of functions too lavishly and imprecisely defined: which functions were identified and how was their impact measured beyond the site itself? A point already raised critically by Smith (2016). This practice can lead to the attribution of any built environment as city or town, no matter if they even served as habitation site (e.g. Rogers 2017). In this case, the definition as a city loses heuristic meaning and, alongside this, its usefulness to differentiate variety in human behavior.

But let us return to the question at hand: from the plethora of different approaches to urbanism, a certain unity among scholars emerges on the simple conclusion that there are no universal criteria fitting every case. Instead, we have to choose criteria that fit the question at hand; and we need to set cities and central places into relation to other forms of habitation within the region and period under study. For this reason, we adopted Michael E. Smith's list of attributes which incorporates all critical features except for the juridical definition of cities (Table 1). This last concept of a juridical definition is based on emic perspectives of a legal status, such as a town charter or the right to serve a market. One rapidly encounters methodological obstacles in the application of this criterion: not only do these concepts derive from medieval Europe, but they are also only evident in written sources, as they are defined by distinct laws.

For societal systems that did not operate with such binding institutions, one has to come up with different criteria. Smith provides exactly such criteria or attributes based on two principles: first, they were part of earlier theoretical schemes, and second, they can be analyzed by means of archaeological data (Smith 2016: 158). The first group of attributes deals with city size and demography. Although as explained above, these attributes are insufficient taken by themselves, size still matters. Taking functions irrespective of settlement size as only criteria leads to misleading attribution as shown above. Smith's second group, subsumed under "social impact (urban functions)," contains political and economic functions and their impact on the hinterland. Administrative (civic architecture), productive (crafts), and distributive (markets) functions are scaled dependent on their impact from low to high. The attributes of "built environment" can be easily deducted from cities' maps. They provide a description of the city's infrastructure. Last, "social and economic features" explore the social makeup of the city's population (for further 
Table 1 List of attributes of urbanism, after Michael E. Smith 2016

\begin{tabular}{lll}
\hline Attributes & & Type of Variable \\
\hline Settlement Size & population & $\mathrm{M}$ \\
& area & $\mathrm{M}$ \\
Social Impact (urban functions) & rensity & $\mathrm{M}$ \\
& royal palace & $\mathrm{P} / \mathrm{A}$ \\
& large (high-order) temples & $\mathrm{P} / \mathrm{A}$ \\
& civic architecture & $\mathrm{P} / \mathrm{A}$ \\
& craft production & $\mathrm{S}$ \\
& market or shops & $\mathrm{S}$ \\
Built Environment & fortifications & $\mathrm{S}$ \\
& gates & $\mathrm{P} / \mathrm{A}$ \\
& connective infrastructure & $\mathrm{P} / \mathrm{A}$ \\
& intermediate-order temples & $\mathrm{P} / \mathrm{A}$ \\
& residences, lower elite & $\mathrm{P} / \mathrm{A}$ \\
& formal public space & $\mathrm{P} / \mathrm{A}$ \\
& planning of epicenter & $\mathrm{P} / \mathrm{A}$ \\
& burials, lower elite & $\mathrm{P} / \mathrm{A}$ \\
& social diversity (nonclass) & $\mathrm{P} / \mathrm{A}$ \\
& neighborhoods & $\mathrm{P} / \mathrm{A}$ \\
& agriculture within settlement & $\mathrm{P} / \mathrm{A}$ \\
& imports & $\mathrm{P} / \mathrm{A}$ \\
& & $\mathrm{S}$ \\
\hline
\end{tabular}

M: quantitative measurement

P/A: presense/absence

S: measurement scale (1: low, 2: moderate, 3 : high) discussion, see Smith 2016). Smith's list provides a systematic approach that allows for easy transference to any cultural complex.

The criteria are not bound geographically or temporally and thus facilitate transcultural comparisons. Furthermore, as Smith himself points out, the scheme is open to addition if needed for specific environments. While the attributes within the group of "social impact" elucidate the relation to the hinterland up to a certain degree from the perspective of the city, we feel it necessary to enhance the discussion with regard to the hinterland. What kind of sites are located within the vicinity of the site in question and which functions might they have performed for the city? The establishment of a functioning supply is crucial for the survival of a city especially during the early days of its existence. A change of perspective is needed and the discussion of city-hinterland relations deserves broader space. We will therefore discuss this aspect separately.

To make one last point before we dive into the analysis of Karakorum: it is not Smith's aim to provide yet another definition of the city. His scheme has a different goal: "In the realm of cities, instead of asking whether a site was a city, we will learn more by asking which attributes of urbanism were present at what level or concentration at a site" (Smith 2016:
160). Thus, these 21 attributes or traits need not be ticked off and at the end we will know, Karakorum was a city or not, but we will know how Karakorum was a city. Urbanism is highly varied across time and space; these traits help to understand the particular configuration of urbanism in a steppe environment during the Mongol Empire. Consequently, there are no clear-cut boundaries, but a high degree of flexibility to erudite "the inherent complexity of ancient urbanism" (Smith 2016: 158). Some scholars who see the goal of archaeology in the production of exact science of empirical, testable data might be concerned with this level of fuzziness. This level of fuzziness, however, can be seen as a chance and unique feature of an archaeology that is nearer to the humanities: we discuss these sites not with respect to how they differ but how they are similar, in order to identify essential attributes of urbanism in the Mongolian steppes. This endeavor echoes Dorothee Kimmich's manifest on the concept of similarity in cultural studies from 2017. Thinking in similarities allows for a flexible construction of lifeworlds, where the supposed exactness of difference and identification - in our case: is it a city or not - produces mistakes or inadequate representations of ancient societies. Kimmich finds fault in arbitrarily set lines where there are none and highlights similarity as "fundamentale Erkenntniskategorie und handlungsleitende Orientierung zu 
den wichtigsten 'tools' kulturtheoretischer Reflexion" (Kimmich 2017: 12). She traces the concept of thinking in similarities in philosophical and cultural studies and through this exploration describes what is at the heart of Smith's approach of 21 attributes: "Grenzen müssen fließend sein, weil Kategorien sonst die notwendigen Anpassungsleistungen an semantische aber eben auch an soziale, kulturelle, historische und politische Veränderungen nicht leisten könnten" (Kimmich 2017: 29). In this way, the openness and vagueness of the approach are rather to be seen as strengths, which is in accord with the partial nature of archaeological remains. And in answer to the question introducing this paragraph: yes, we will refer to Karakorum as a city throughout the text by the simple argument that it was the capital of a world empire. In the next sections, we explore what a city in the steppe actually means.

\section{Closing in on Karakorum: The city in the steppe}

The 21 traits as compiled by Michael E. Smith (2016) are presented in the following for the case study of Karakorum, enhanced by the discussion of hinterland-city relations. The past 20 years has witnessed an intensification of archaeological research in and around the site (Bemmann 2014: 14-18). Many of the attributes addressed below were in some form or combination the subject of earlier works. While we deem Karakorum to be the most thoroughly researched fixed settlement in Mongolia, our knowledge is - not surprisingly within the field of archaeology - imperfect. Especially the critique of stasis as put forward with regard to Christaller's theory of central places, we, too, cannot escape, since we take Karakorum in its latest appearance as representative for its complete time of use. The same is true for all other sites discussed within this text. In most cases, we cannot even clearly identify the times of foundation, use, and abandoning of the sites due to a lack of precise and detailed chronological systems and having to work with insufficient excavation data. In the face of these challenges, we still think it worthwhile to discuss our material as scant as it may be within the context of urbanism. Apart from making progress in understanding and explaining urban phenomena in the steppe, the discussion will crystallize fields in which we need to focus future efforts. The present paper is the first to draw these scattered data together in a concise form.

Karakorum lies within Central Mongolia in the valley of the Orkhon River (Fig. 1). To the south backed by hills, the city lies on top of a gravel fan at the mouth of the valley that opens here to a width of $24 \mathrm{~km}$ and stretches $70 \mathrm{~km}$ to the north before it restricts again (Mackens et al. 2017). The nearby Orkhon supplied year-round fresh water, and the region is known for its comparatively fertile soils. Combined with a deep history of steppe empires, which invested high political and ideological meaning in this valley, the Great Khans had ample reason to choose this site as the location for their first capital (Allsen 1996; Di Cosmo 2014/15). In the Mongols' cultural memory of the thirteenth and fourteenth centuries, Chinggis Khan is named as the founder of the city and 1220 is given as its founding year (Cleaves 1952; Pelliot 1925). However, as Klaus Sagaster underlines, a philologically exact translation of the text shows that Chinggis Khan designated Karakorum as capital or residence - in his opinion, the Chinese word " $d u$ 都” can signify both, while the Mongol version of the inscription indicates a clear preference for residence (Sagaster 2005: 151). Accordingly, Chinggis Khan chose a place for a camp, and this decision did not comprise the construction of permanent and locally fixed architecture. Construction work began under the second Khan, Ögödei, from 1235 (Abramowski 1976), and the city was presumably occupied into the early decades of the fifteenth century (Reichert 2019).

\subsection{Settlement size}

Karakorum's size is not easily determined, as the built lived area extends beyond the bounding city wall. The area inside the city wall without Erdene Zuu covers 135 ha. If one includes the several suburban sites and the buildings along the road that stretch from the eastern main gate to the southeast, the area extends over about 1300 ha. At the same time, the density of building constructions and size of plots varies within as well as outside of the outer city wall immensely (Fig. 2). Furthermore, certain environmental constraints need to be mentioned: the growth of the city was naturally bounded to the west by the inundation area of the Orkhon River.

Concerning the demography of Karakorum, the number of inhabitants is not exactly mentioned in the sources. Because of William of Rubruck's comparison of Karakorum to Saint Denis we can calculate the number of inhabitants to roughly 7000 to 12,000 people for the year of the monk's visit to Karakorum in 1254 (Reichert 2020). Another number stems from written accounts of population movements ordered by the Great Khans. Commanded by Ögödei Khan, the palace area was enclosed by a wall or an earth rampart already in 1235 as described in the Yuan shi 元史 (History of Yuan) (Yuan shi: chapter 2; Abramowski 1976: 130). No exact numbers of workers are given for this episode. However, the fourth Khan, Möngke, stopped the development of Karakorum and disbanded 1500 Chinese workers who worked on the enclosing city wall in 1251 (Yuan shi: chapter 3; Abramowski 1979: 20). Whether these people were the same workers who were moved to Karakorum in 1235 cannot be decided, but one should keep in mind that the palace had been completed and inaugurated during the 
Fig. 2 Map of Karakorum and its surroundings (@) Sven Linzen, IPHT Jena 2019, used with permission)

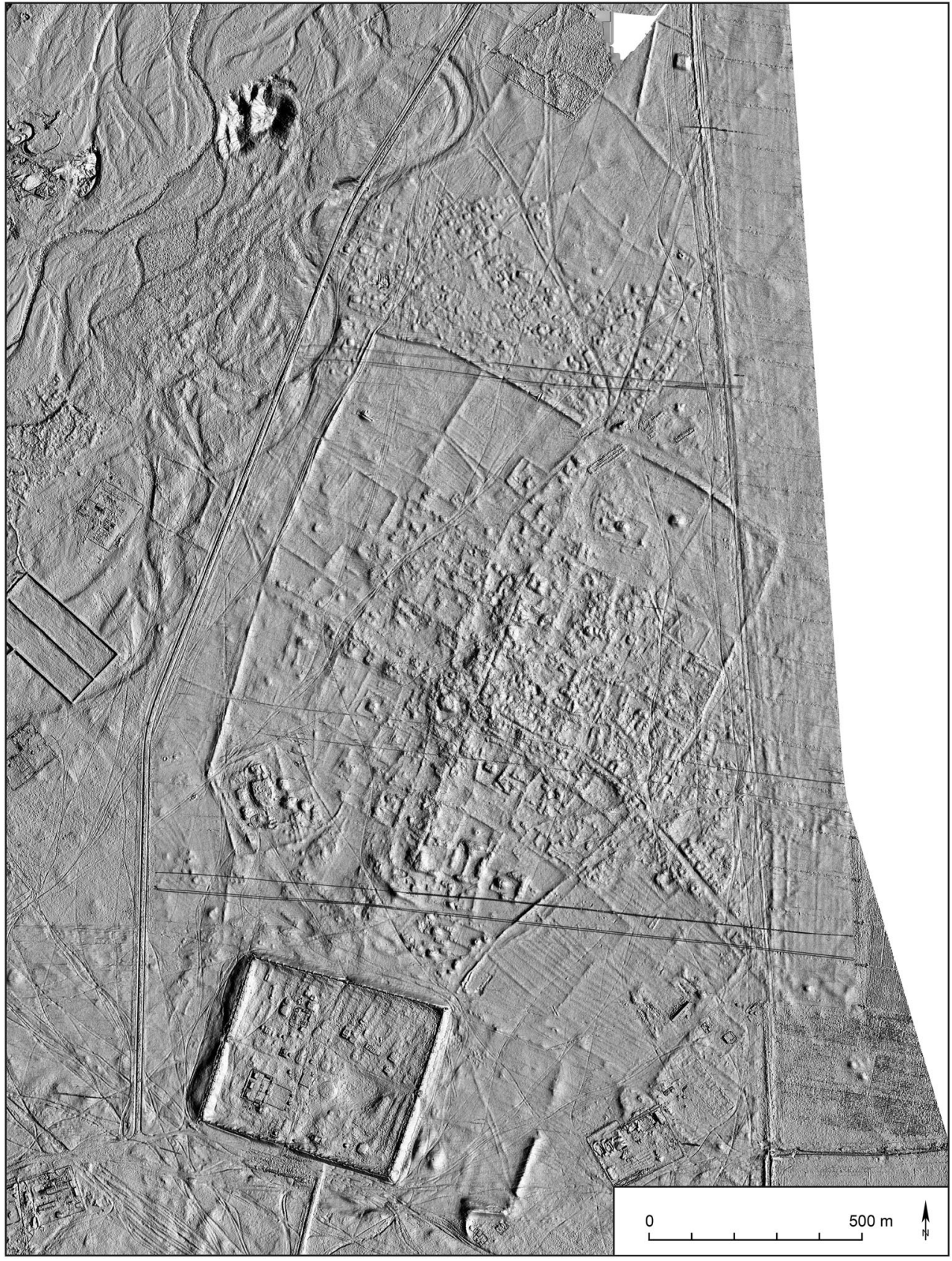

spring of 1236 (Abramowski 1976: 131). Be that as it may, in 1252, Möngke again resettled 500 families of varying craftsmen to Karakorum to fulfill work on the palace (Yuan shi: chapter 3; Abramowski 1979: 21). 9500 soldiers were ordered to Karakorum in 1309 (Yuan shi: 23, 510). Two years prior the emperor entrusted 10,000 Han soldiers stationed there with fields to cultivate (Yuan shi: 22, 492), which indicates a permanently stationed garrison troop of such size at Karakorum (Dardess 1972/73). The total number of troops in Mongolia is estimated at 150,000 men (Hsiao 1978: 59). Considering the population estimates, however, we must bear in mind the seasonality of habitation at the site and differing intensities in occupation across the city area. The Khan's court did not reside constantly at Karakorum, but rather migrated between several camps during the cycle of the year (Boyle 1974a; Shiraishi 2004). William of Rubruck observed that Möngke went twice a year to Karakorum, once during spring ("at Easter"), and another time in summer (Rubruck and Jackson 1990: 209). Merchants and their personnel surely were likewise on the move as their trade demanded, presumably from spring to fall in most cases.

As one can discern on the city map, the density of building constructions and the thickness of occupation layers 
fluctuates enormously within the walled area (Fig. 2). While the area around the central street crossroads comprises cultural layers of up to $5 \mathrm{~m}$ thickness with at least nine phases of use (Reichert 2019), the northern parts and presumably southern areas are only slightly elevated compared to the original topography and might provide only one or two use phases. Thus, the density of population varied from season to season, from quarter to quarter, and of course along the timeline. The shifting of the court to Dadu, the reduction to the tasks of a regional town, fighting within the area between Khubilai and Arigh Böke, and later with Qaidu, along with the sacking of the city (Dardess 1972/73), all probably left their mark on the demographic development. As William of Rubruck experienced Karakorum during one of Möngke's rare visits, his comparison probably accounts for a moment of increased population. Bearing these restrictions in mind and grounding our numbers on Rubruck's observations, we can assume a general population density of about 44 to 75 inhabitants per hectare for Karakorum if taking only the walled perimeter, and a much looser population of five to nine persons per hectare if we include the outlying, dispersed compounds. The former ratio corresponds well with published data of population densities from Mesoamerican Aztec sites (Smith 2016: 162 Table 10.2). Although we should keep in mind that Rubruck visited Karakorum only 19 years after the construction begun.

\subsection{Social impact}

The existence of an imperial palace at Karakorum is known from several written sources: William of Rubruck, for example, provides a detailed description of the residence (Rubruck and Jackson 1990: 209-212). The identification of the physical remains of the building on the actual site, however, took archaeologists a good part of the twentieth century and the beginning of the twenty-first century. Still, it must be admitted that the question is not yet entirely resolved. As a possible candidate for the Khan's palace, Soviet archaeologists focused on a large building complex within the southwest of the enclosing wall, the orientation of which lay at odds with the overall orientation of the city and features within the city (Figs. 3 and 4). Sergei V. Kiselev, who conducted the first larger excavation of this complex in 1947 and 1948, thought they had discovered the palace (Kiselev 1965). Conspicuous finds of Buddhist nature he attributed to post-settlement use. His interpretation of the complex as the Khan's palace found ready reception in the publications of historians, art historians, architects, science journalists, and other archaeologists (Phillips 1969; Shatzman Steinhardt 1988; Shiraishi 2002; Dmitriev 2011). Renewed and large-scale exposure, as well as meticulous interpretation of the remains, led to the identification of this complex as a Buddhist temple, probably the
"Pavilion of the Rising Yuan" mentioned in written sources (Cleaves 1952: 23; Franken 2015: 161-162). The grandeur of the reconstructed architecture, which unites religious ideas from Tibet and architectural know-how from China, highlights the ranking of this structure as a large temple of a higher order (Franken 2015: 157; Muping 2015). The Buddhist sculpture in the temple was up to $7 \mathrm{~m}$ high (Hüttel 2009: 542), and, following Franken (2015: 140), the building can only be hypothetically reconstructed to a minimum height of $9 \mathrm{~m}$ and a probable height of perhaps 35 to $38 \mathrm{~m}$. The inscription of 1346 describes a five story building of 300 chi height (Cleaves 1952), presumably ca. $90 \mathrm{~m}$. Taking into consideration that the inscription was placed on the back of a turtle more or less in front of the temple, the mentioned height should not differ significantly from its actual height. Temples of this size presumably attracted a larger community and must have operated almost as a magnet for the entire region. The temple must have been visible from far away and was without doubt constructed as a landmark building. The presumable temple complex in the other city of the Mongol empire period, Khar Khul Khaany Balgas, lies at a similar spot in relation to the palace compared to the one at Karakorum and with its accompanying buildings takes up the largest area of the city after the palace area, as is the case at Karakorum (Moriyasu and Ochir 1999: pl. 19a-b; Shiraishi 2002: 278, fig. 3-61) (Fig. 5). The digressing orientation of both temples might be explained with religious reasons, to align the corners of the buildings approximately with the cardinals following the Mandala principle (see Franken 2015: 145). The aforementioned inscription of 1346 (Cleaves 1952) associated with Karakorum's landmark, the stone turtle, also bears witness to the eventful building history of the temple. The latter is also inscribed into the course and sequence of the enclosing walls. Four kilns, used for the firing of building materials needed for the redevelopment of the temple, sat on an older wall and ditch structure (Franken 2005: 147). The inscription stone itself is a rarity in Mongolia. Only three more sites with free standing stones are known from the Mongol Empire period: one from Khirkhira in Transbaikalia (the earliest, the so-called Chinggis Stone; Elichina 2005; de Rachewiltz and Rybatzki 2010: 160-165), one from the socalled Möngke's palace west of Mörön, Khuvsgul aimag (Moriyasu and Ochir 1999: 254-260; Poppe 1961; Rinčen 1959), and a third one from Khubilai Khan city (Moriyasu and Ochir 1999: 261-265; de Rachewiltz 1987). The only stone turtles we know of from the Mongol period are all located at or nearby Karakorum, which underlines its special position as former capital of the united Mongol empire and later capital of the province Lingbei.

The location of the palace, however, has to be looked for underneath the Buddhist monastery from the end of the sixteenth century, Erdene Zuu, which is still active today. Six trenches along the walls of Erdene Zuu and one south of the 
Fig. 3 Geomagnetic map of the Buddhist temple in Karakorum measured by a team from Bonn University in 1999, at that time this area was thought to be the palace area of the capital. Greyscale displays a dynamic range of $14 \mathrm{nT}(-7 \mathrm{nT}$ to $+7 \mathrm{nT})$ (after Mommsen et al. 2001: 74 Fig. 2)

Fig. 4 Map of the Buddhist temple in Karakorum as drawn by Radloff and his topographer I.I. Shchegolev in 1891 (detail after Radloff 1892: pl. 36.2)
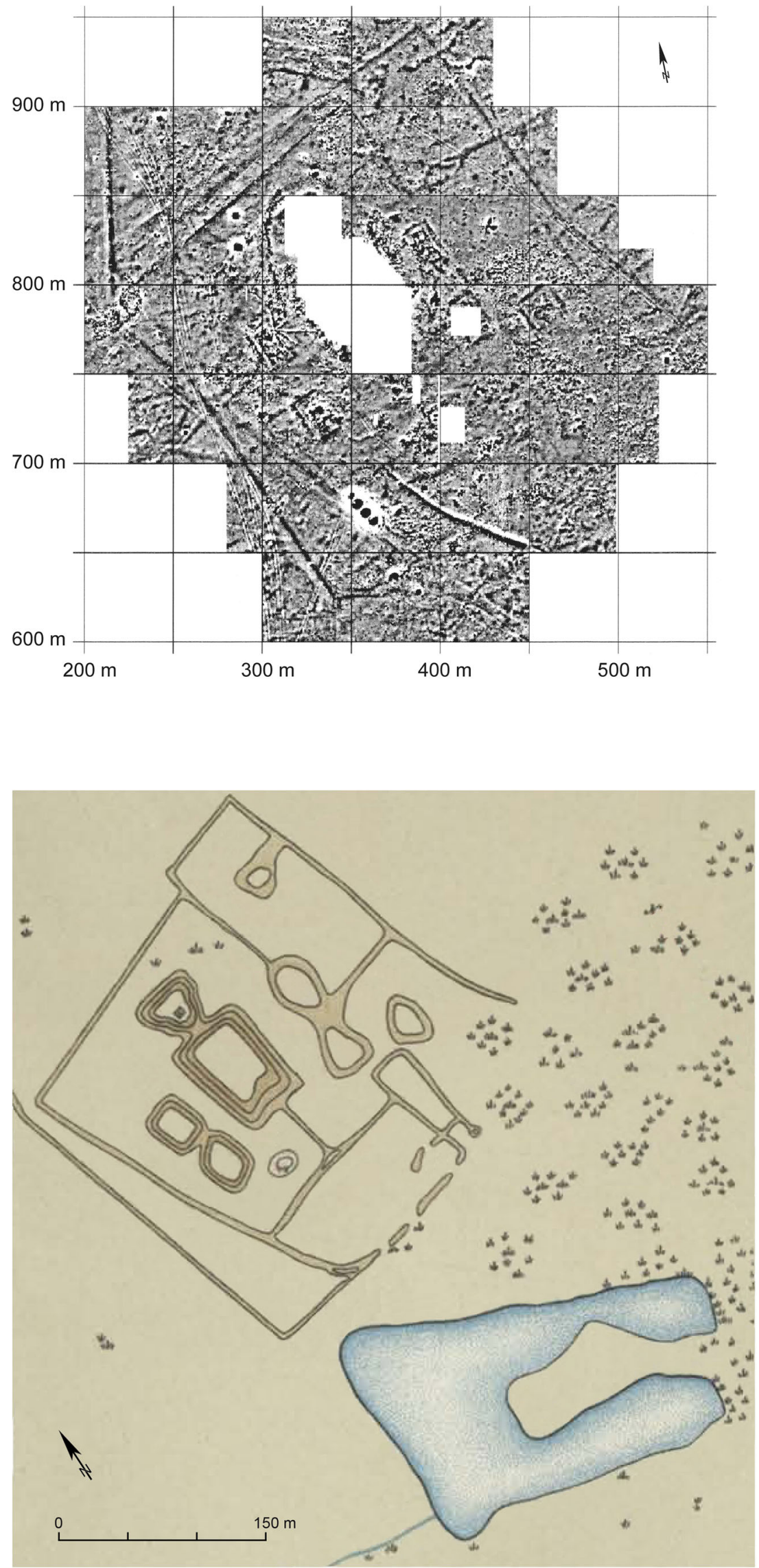
Fig. 5 Map of Khar Khul Khaany with presumable temple (after Shiraishi 2002: 278, Fig. 3-61)

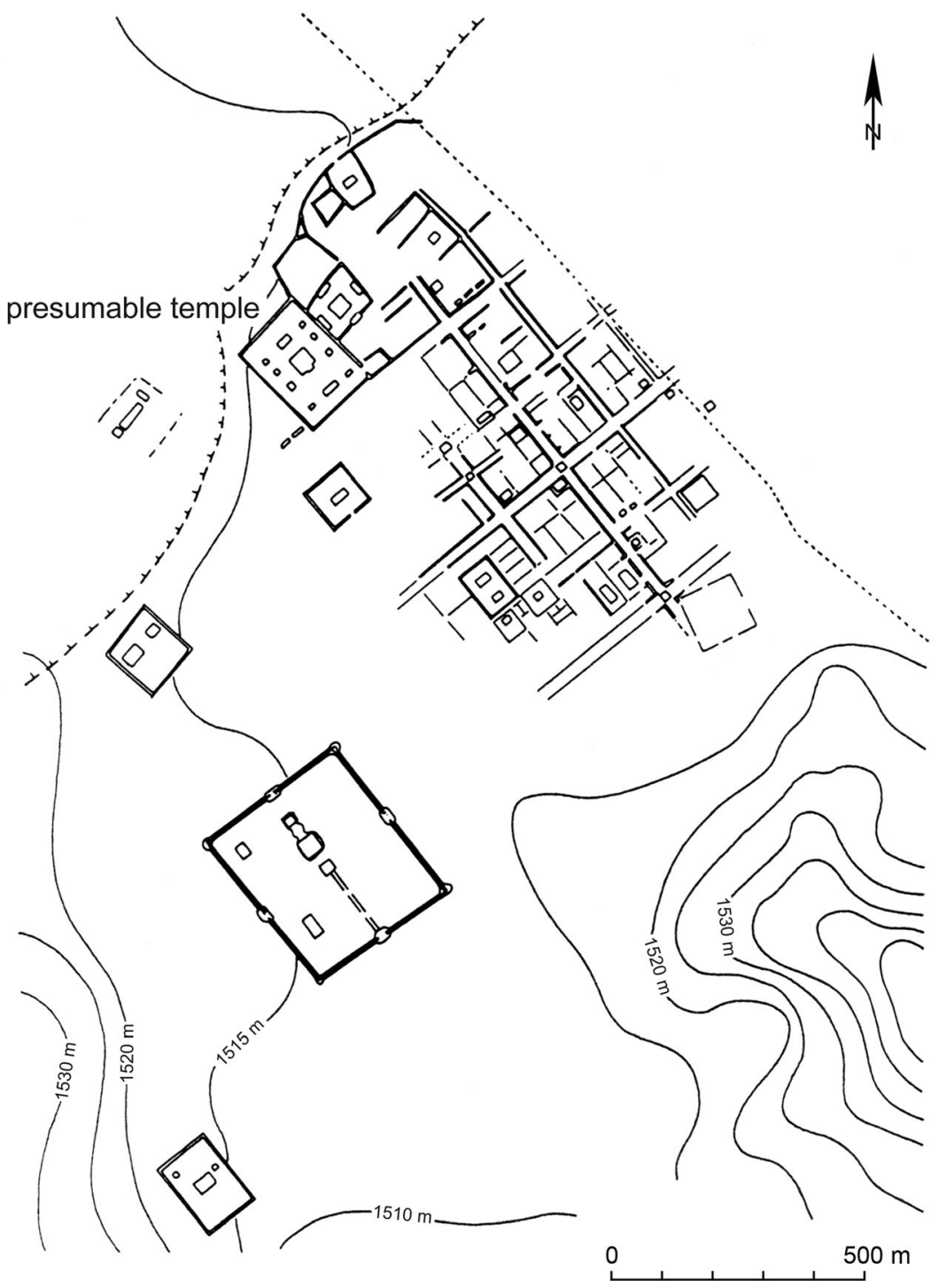

eastern gate of this fence showed earlier wall structures underneath that have been dated to the early thirteenth century via thermoluminescence and radiocarbon analyses (Erdenebat 2011). These partially exposed walls presumably enclosed the actual palace area of Karakorum (Franken 2012/2013: 366-368; Franken et al. 2014: 368-372; Hüttel 2007). Out of respect for the current occupants, no further excavations within the walls of the monastery are yet planned, and the location of the palace remains hypothetical. The hypothesis, however, gains further weight if we reconsider William of Rubruck's description of the palace's location relative to the city itself: "At Caracorum Mangu [Möngke Khan] has a large encampment, near [emphasis by authors] the city walls and enclosed by a brick wall (...)" (Rubruck and Jackson 1990: 209). This depiction matches the relative location of Erdene Zuu with regard to the main body of the city. Thus, we do not dispose over the actual physical remains of the former Khan's palace, but we can be fairly certain about its location. Furthermore, William of Rubruck provides a description of the palace itself: "The palace resembles a church, with a middle nave and two sides beyond two rows of pillars and three doors on the south side. The tree [i.e., a silver well manufactured by the French artisan Guillaume Boucher] stands inside, opposite the middle door, and the Chan sits at the northern end, in an elevated position so that he is visible to all" (Rubruck and Jackson 1990: 210). Although we do not have any material evidence of the palace itself, we do have buildings excavated elsewhere that are interpreted as palaces of the upper elite. Again, it was Sergei Kiselev who conducted excavations at the site of Kondui, located in Siberia in the Transbaikalian region (Fig. 6). This site is interpreted as an imperial residence of the Mongol period. Its central complex, with rows of column bases oriented north-south, formed a wider middle nave and two naves to the sides (Kiselev 1965: 
Fig. 6 Map of the palace of Kondui (after Kiselev 1965)

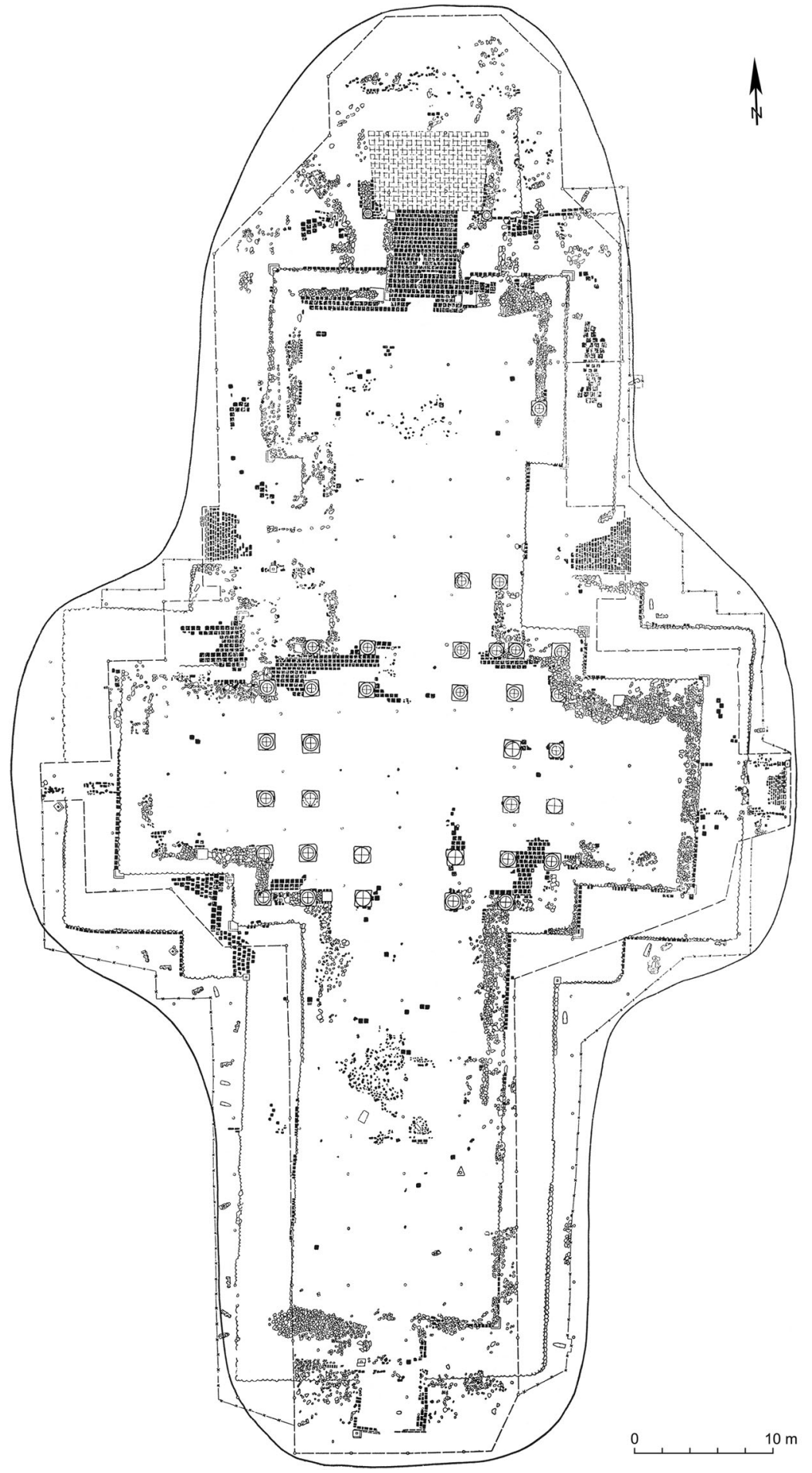

Fig. 171; Kradin and Baksheeva 2018: 311 Fig. 9.11). The hall that had been supported by these column bases alone must have been of impressive size, notwithstanding outer architectural components as can be discerned on the published map. Following the extent of the stone bases as depicted by Kiselev, the area of the upstanding structure covered about $24 \times 21 \mathrm{~m}$ $\left(504 \mathrm{~m}^{2}\right)$. The structural components emit a striking similarity to Rubruck's description. Rashīd al-Dīn also mentions the construction of the palace area carried out by Chinese craftsmen: "Each side was an arrow shot in length, and in the middle was raised a pavilion of great height. The buildings were decorated as elaborately as possible and ornamented with the skills of painters and artists." (Thackston 1998/1999 II: 670). The length probably refers to the side length of the walled 
palace area. The ground plan of the buildings is reminiscent of a Christian cross, which gives further weight to this impression. However, it goes without saying that a similar building as palace of Karakorum is highly hypothetical. The so-called palace building in Avraga, a Mongol-period settlement near the Kherlen River, is much smaller and differs completely in its layout (see Shiraishi and Tsogtbaatar 2009: 553-556). If monumentality and size are related to meaning, it is evident that the palace area, and that also means the ruler, is placed at number one and the Buddhist temple is at second place.

Until now, no burials of the ruling elite have been identified in the Orkhon valley. Going back to an anecdote told by Rashīd al-Dīn about how Chinggis Khan chose his own burial place, it is assumed that the burials of the khans took place in the three-river region of Kherlen, Onon, and Tuul in the heartland of the Mongol tribe (Thackston 1998/1999: 261; de Rachewiltz 2004/SHM §179, 102; Yuan shi: 1, 11; but see Boyle 1970). The self-chosen place of burial around the mountain Burkhan Khaldun was even declared under UNCESO World Heritage Protection (https://whc.unesco. org/en/list/1440). In this way the different ideological position of Karakorum in comparison to the Kherlen region is expressed. According to Christopher Atwood (2015), varying ideological and legitimatory preferences found their expression in the choice of residences of the respective khans. Literary accounts suggest a varied burial practice according to social rank, in which the burial grounds of the highest social members were kept secret and did not display any major above ground markers (Boyle 1974b; see also Allsen 1996). The most elaborate burials known so far are those from Tavan Tolgor̆, Sukhbaatar aimag. One even contained a seal, another one a folding chair (Turbat and Batsukh 2015; Törbat 2015).

Smith does not provide a clear idea of what he meant by his attribute of civic architecture (Smith 2016). As its social impact and reach, ranging from intra-site to wider region or hinterland, need to be evaluated, we assume it to mean communally used buildings such as assembly halls or other administrative buildings. Archaeological works did not reveal any structures that might be attributed to any such function. According to Rubruck, the Great Khan's separated palace compound comprised storage buildings which were also mentioned by Rashīd al-Dīn. Nobles within a distance of twomonths-journey gathered here when the khan resided at Karakorum to receive gifts (Rubruck and Jackson 1990: 209). Ögödei encouraged them to build residences nearby his palace at Karakorum as is told by Rashīd al-Dīn (Thackston 1998/1999 I: 670-671). Although we lack physical remains, we can still assume a far-reaching impact of Karakorum during its time as capital. Court secretaries likewise had palaces separated from the Muslim and Chinese communities of Karakorum (Rubruck and Jackson 1990: 221). The find of an administrative seal from the post-Yuan era underlines the fact that Karakorum kept wide-reaching administrative function (Pohl 2005).

A part of the city which is probably identical with the artisans' quarter mentioned by Rubruck was excavated from 2000 to 2005 (Reichert 2020). Large kilns were erected close to the Buddhist temple, and further away, in the inundation area of the Orkhon, a whole line of kilns was excavated (Hüttel 2012a; Franken 2005). While these kilns presumably produced building materials intended for use in Karakorum itself, the impact of craft production in the middle of the city extends probably beyond the constraints of the city: Apart from the manufacture of items for elite consumption, bone cutting and services like mending of vessels might have served a larger hinterland of Karakorum (Reichert 2020).

The data concerning markets at Karakorum remain unsatisfying: Rubruck describes different markets at all four main gates, each specializing in a certain commodity. "At the east gate are sold millet and other kinds of grain, though they are seldom imported; at the western, sheep and goats are on sale; at the southern, cattle and wagons; and at the northern, horses" (Rubruck and Jackson 1990: 221). Furthermore, he mentions "a bazaar and fair" within the so-called Saracen quarter, which might have functioned as shops (Rubruck and Jackson 1990: 211). Rashīd al-Dīn cursorily mentions a market and storehouses at Karakorum (Thackston 1998/1999 I: 955; see also Allsen 2019: 44). None of these activities, which must have left some material remains, have been identified so far in the archaeological record. Neither can they be observed by outer appearance alone on the city map. Though the existence of markets is reliably witnessed, we do not know who had access to them. Did they only serve the population of Karakorum proper or a larger audience? In analogy to craft production, one can presume a wider circle of customers enjoying the offered wares, although we do not yet have the data to support this claim. According to the written sources, a clear distinction can be made between a local trade at the gates, with local products, and a long-distance trade with its products in the Muslim neighborhood. This observation might reflect a different clientele and participation and perhaps also efforts to keep the nomads and their animals out of the walled part of the city.

Another attribute not clearly listed by Smith is the function of the city as a military base. After the establishment of the province Lingbei with Karakorum as its administrative center, the city became the station of a military garrison with accompanying storehouses for provisions (Lech 1968: 112; Dardess 1972/ 73). The military garrison is mentioned several times in the Yuan shi since 1283 (Yuan shi: chapter 58; Cleaves 1952: 26).

\subsection{Built environment}

A city wall with gates is mentioned in the written sources erected on behalf of Ögödei in 1235 - and was partly 
excavated (Kiselev 1965). Because of its relatively small height and built, the defensive function of the outer wall had been rightfully questioned (Kiselev and Merpert 1965: 173; Dardess 1972/73: 118). The construction of the wall of rammed earth layers (hang $t u$ 艻土) but without brick cladding could be exemplified by recent excavations of a MongolianIsraeli-German team in the northern extremity of the city (see Fig. 7). A radiocarbon date from charcoal that was uncovered outside the actual wall and which probably stemmed from a wooden parapet yields a time frame of 1291 to $1401 \mathrm{cal} \mathrm{AD}$ (95.4\%, calibrated with OxCal v. 4.2.3 and IntCal13; Bronk Ramsey 2013; Reimer et al. 2013; laboratory number: COL2896.1.1). Walls with brick cladding are commonly found in contemporary Chinese cities, and apart from aesthetic considerations, they provided protection from erosion as well as defensive functions (Turnbull 2009). The outer wall of Karakorum might thus be more of a demarcation line, ostentatiously showing the extent of the Great Khan's possession and controlling access to the city proper. After all, Karakorum is still the only Mongol period city in Mongolia with an extended outer wall. The wall units at Avraga are so inconspicuous that they are barely discernible on site (Shiraishi 2002; Tsogtbaatar et al. 2017). Walls also structure the inner city area of Karakorum, including specific building complexes, which are separated, and larger neighborhoods. The palace area was surrounded by a mighty rampart veneered with fired bricks $-8 \mathrm{~m}$ thick and much wider than the current rampart of the Erdene Zuu monastery (Hüttel 2009: 546-547). The same can be observed in the city of Khar Khul Khaany: The residence of the ruler is protected by impressive walls and access to it is regulated by four gates (Moriyasu and Ochir 1999: Pl. 19a).

Access to the city area of Karakorum proper was likewise channeled through four gates, as mentioned by Rubruck (Rubruck and Jackson 1990: 221). Old mappings of the ruins at Karakorum show several openings within the wall to which streets lead (Kato 1997). Thus, we reckon with a multitude of gates and apertures of varying sizes and construction on top of the mere four gates mentioned by Rubruck. Kiselev concentrated his efforts on the eastern main gate as the gateway to China (Kiselev and Merpert 1965: 174-175). Unfortunately, the publication of his results posthumously does not allow for a clear picture of the gate (Kiselev and Merpert 1965: Fig. 100).

Connective infrastructure within the city is dominated by a central intersection of two streets running N-S and E-W and leading towards the four main gates. These large main roads divide the city into four quarters, lead beyond the city limits, create a connection to the hinterland, connect to the important overland routes, and cut deeply into the landscape. The smaller inner-city traffic routes, the construction of which was probably less complex, are a visual contrast. The roughly northsouth running main road, which was carefully paved during one of the first settlement phases, was revealed during excavations within the middle of the city (Pohl 2010). Stone plates of slate were carefully placed on the levelled ground and separated by wooden beams into rectangular fields of roughly $3 \times$ $2.8 \mathrm{~m}$ on average, thus forming a $5.6 \mathrm{~m}$ wide street (see Fig. 8). The beams probably functioned as a buffer for the considerable variations in temperature. At some point during the use phase of this street, ditches lined with wood were constructed alongside the pavement. The paved street, however, served for only about one generation, after which new street surfaces were placed on top of the old road by using settlement refuse, as is discernible by massive animal bone waste within the street levels topped by gravel as new road surface. From about the turn of the thirteenth to fourteenth century until the latest clearly established settlement phase after the demise of the Mongol Yuan dynasty in 1368, this procedure had been repeated at least four times, now and then in connection with maintenance works on the accompanying ditches. These endeavors speak for a continued interest and investment in the infrastructure, even though at a lower rate than during the earliest street construction. Further connective infrastructure is observable on the city map, which shows several linear structures, most likely streets. Recent geomagnetic measurements demonstrate the continuation of roads outside the city, extending from the eastern main gate to the southeast, northeast, northwest, and west (Fig. 2). Whether

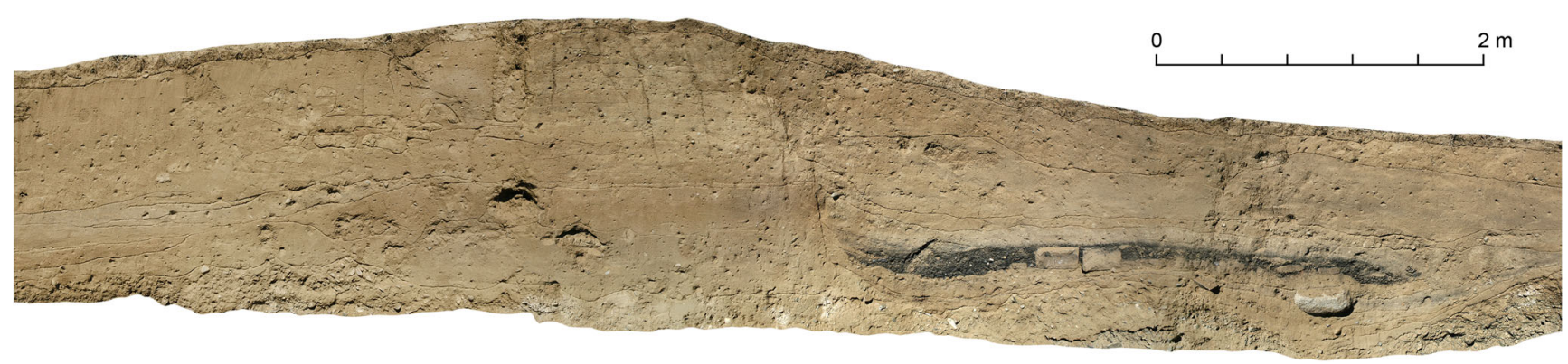

Fig. 7 Section through the northern part of the outer city wall of Karakorum. The section is located nearby the assumed northern main gate to the northwest, taken in 2014 (photo @ Bonn University, used with permission) 
Fig. 8 Excavation photograph of the exposed main street in the city center of Karakorum, taken in 2003 (photo (C) Bonn University, used with permission)

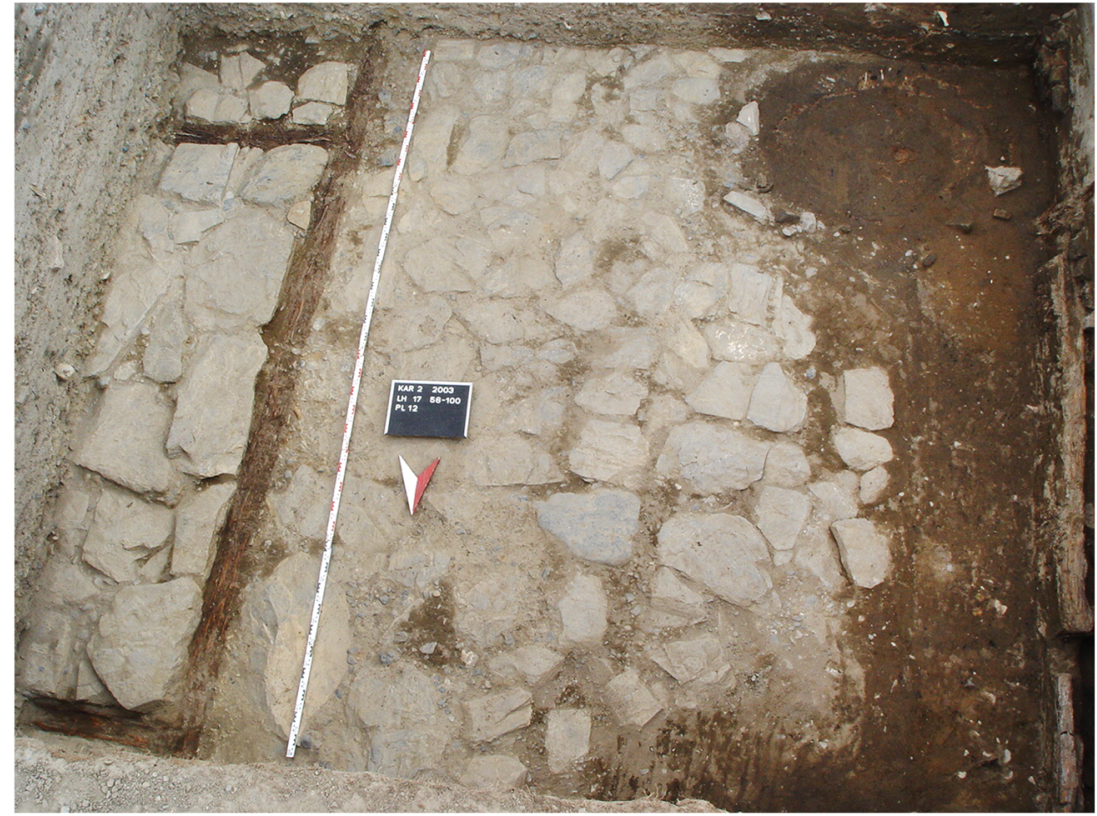

these traces are the result of heavy use of the same path or are an actual built road needs to be verified by targeted excavation.

As of yet, there are no indications for the existence of water management, as clear remains of wells, water pipes, or other conduits are missing. The only measure taken with regard to water management are the ditches observed alongside the road, which captured and allowed for the movement of superfluous surface water. A track that is discernible on the topographic map leads from the western main gate to a meander of the Orkhon River; probably the place to fetch fresh water (Fig. 2). It is not known whether the Orkhon was also used for transport purposes, e.g., to bring building materials from the quarries in the upper part of the valley to the city center.

Rubruck mentioned twelve heathen temples, two mosques, and one church (Rubruck and Jackson 1990: 221). The excavator Hans-Georg Hüttel thinks that a building in the northeast sector of the city was erected for religious services (Hüttel 2012b). Judging by its comparative size to the aforementioned Buddhist temple, this complex would presumably belong to intermediate-order temples. The interpretation as a possible Nestorian church, later remodeled as Buddhist temple, suggested by the excavator (Hüttel 2012b), cannot be verified, as full publication of these excavations is still awaited. Rubruck's description has proved rather reliable so far, so we can therefore assume that there was a variety of minor religious places of congregation in Karakorum. Until now, however, we were unable to identify any other complexes with any certainty. There are, for example, no other buildings with a deviant layout such as that of the large Buddhist temple. Inscriptions from the first half of the fourteenth century (Matsuda and Ochir 2013), however, witness several religious institutions and serve to corroborate Rubruck's observations.
A Persian inscription on a stele erected in 1342 draws our attention to a Sufi assembly: “... a khānqāh for followers of the way of Sufi ..." (Isogai and Yajima 2013b). Another Persian inscription stone mentions for 1332 “...a waqf [endowment under Islamic law] of three houses for the benefit of the masjid [mosque] ..." (Isogai and Yajima 2013a). In addition, inscriptions name a shrine for the Three Sovereigns mythological rulers in ancient northern China - a Confucius Shrine, and a San ling hou miao 三靈侯廟 shrine (Matsuda and Ochir 2013). The written sources thus paint a vivid picture of a multitude of different persuasions and belief systems all with their own assembly places or places of worship at Karakorum.

As already mentioned, Ögödei encouraged the Mongol nobility to construct houses near his residence (Rashīd al-Dīn and Boyle 1971: 61-62). None of the excavated areas have yet yielded sufficient evidence for an elite attribution to any of these structures. Maybe we need to search the residences in the compounds dispersed outside the main body of Karakorum, which were already partially mapped by Radloff (1892: pl. 36).

The political center of the whole city and its surroundings was probably the court of the Khan, but we do not know if there was a formal public place within Karakorum. The city map shows seemingly empty spaces within the northern parts of the walled area, the purpose of which remains open to speculation. The written accounts, however, stay conspicuously silent on this point. Some scholars assume that yurts (Mongolian ger) stood within these areas without permanent building constructions. As of yet, there has been no evidence brought forward to support this claim. On the contrary, written sources do not even mention pastoralists as inhabitants of the city.

In the case of Karakorum, we have strong reasons to assume that Karakorum had been planned from the beginning as 
epicenter: the site was founded as the capital of the Mongol empire, and in answer to differing opinions, we do not have any data that would suggest a prior settlement on the location or evidence for an independent development from the bottom up. Pottery from beneath Erdene Zuu and from surface collections north and west of Erdene Zuu indicates the existence of a Uyghur period settlement in this area (Shiraishi 2011). Our most recent survey's surface finds of typical pottery in the southern direct vicinity of the monastery corroborate a strong presence during the Turko-Uyghur period in that area. Considering the high density of sites of this time in the Orkhon valley, this discovery is not surprising. Karakorum did not grow from a previous settlement but was constructed on the behest of the Mongol Khans as depicted above. As to the question of axial principles related to a cosmological program (Renfrew 2008: 47), there has been a vivid debate on possible models for the layout of Karakorum. One faction favors Chinese ideal cities as models (Shatzman Steinhardt 1990; Pohl 2009: 530); others propose Central Asian precursors (Becker 2012). These suggestions are not entirely convincing as none fit Karakorum's layout and appearance. Karakorum rather evinces the impression of a true pastoralist cosmological program in the broadest sense possible: with the Khan's palace supposedly in the south and the city area stretching to the north, the overall pattern resembles the traditional spatial orientation of the Mongolian yurt or rather ger (Wasilewski 1976). This specific Mongol worldview might explain at the same time why there are barely any traces discernible in the area south of the presumed palace area. Other habitation sites repeat this general outlay, as for example, Khar Khul Khaany Balgas in the Khanui valley (see Fig. 5) and less pronounced, Kondui (Kradin and Baksheeva 2018: 304 Fig. 9.8). While this finding speaks for Mongolian participation in the planning of the city, it is unclear how far this participation went and by whom. Some passages in the written sources suggest at least a certain personal interest of the supreme rulers, such as those concerning the construction of the wall around Karakorum on the Grand Khan's order. At the same time, most architectural styles and techniques identified in Karakorum closely resemble Chinese patterns.

\subsection{Social and economic function}

If one considers that large scale cemeteries are unknown (cf. Erdenebat 2009) but that it was still a privilege to be buried in marked graves, the excavated burials around Karakorum (Bayar and Voitov 2010) likely belong to a lower elite stratum. As of yet, the social stratification of Mongol society based on the material remains of funerary assemblages is a research lacuna that hinders a reliant evaluation of this question. Burial places that can be attributed to the city's inhabitants remain unknown in the surroundings of Khar Khul Khaany Balgas, the next largest city compared to Karakorum in the
Mongolian steppe. The same is true for Avraga, which has been studied much more intensively. The nearest funerary complexes typical of the time lie at a distance of more than $25 \mathrm{~km}$ (Shiraishi and Tsogtbaatar 2013: 7).

With the site of Okoshki, it is alone Khirkhira, in Siberia, for which our Russian colleagues successfully identified a small necropolis of a high-ranking community nearby and contemporary with the settlement (see Fig. 9; Kharinskir et al. 2014; Kharinskiǐ et al. 2019). A second but different example for a cemetery close by a settlement also should be mentioned. Pèrlèe (1961: 92-93) excavated in 1950/51 a small site with permanent houses at Takhilt Us, west of Baga Gazryn Chuluu, Dundgov aimag, and identified a cemetery nearby, where, in his opinion, Chinese were buried. Two Islamic cemeteries in the surroundings of Karakorum pose a unique characteristic in the eastern Eurasian steppe. A large area densely set with funerary buildings beyond the northern city wall is considered to be a cemetery for members of this religion based on the small excavation from 1978 to 1980 (Bayar and Voitov 2010). The Muslim cemetery extends over an area of around 24 ha. Considering that 37 graves had already been discovered in the small area of maximum $1600 \mathrm{~m}^{2}$, about 6600 buried persons could be expected north of the city wall. About $8.5 \mathrm{~km}$ northeast of the city lies a second, rather smaller cemetery, which likewise is said to contain burials of Muslims; the results of the excavations, however, have not yet been published.

The social diversity of the inhabitants is vividly described in several sources; the same is true for ethnic neighborhoods. Rubruck's two "vici," commonly translated as "quarters," of Chinese artisans as one group and Muslim merchants as the other, might be understood in the sense of neighborhoods (Rubruck and Jackson 1990: 212). Many of the artisans were prisoners of war or captives with different origins and statuses, like the famous goldsmith, William Boucher (Rubruck and Jackson 1990: 183; Guzman 2010), and many of the inhabitants of the city did not come voluntarily (Allsen 2015). We reckon, thus, that Karakorum maintained a highly varied permanent population, concerning professions (see Reichert 2020), religious affiliations, and ethnic backgrounds. Additionally, envoys and traders as well as soldiers enriched the makeup of the population. If we take the size of the compounds as an indicator of the rank of the owner, there must have been significant differences. Standardized building forms or floor plans cluster in different areas and along the main streets, which could indicate a social and/or occupational differentiation of the neighborhoods.

With regard to possible farming activities, from the archaeological side, Helmut Roth suggested the existence of irrigation systems, "celtic fields" (Roth 2002: 32-33, pl. 2). These traces, which are visible on the city map, are younger than the city and belong probably to the monastery (Honeychurch and Amartủvshin 2007: 42). Botanical analyses and pollen 


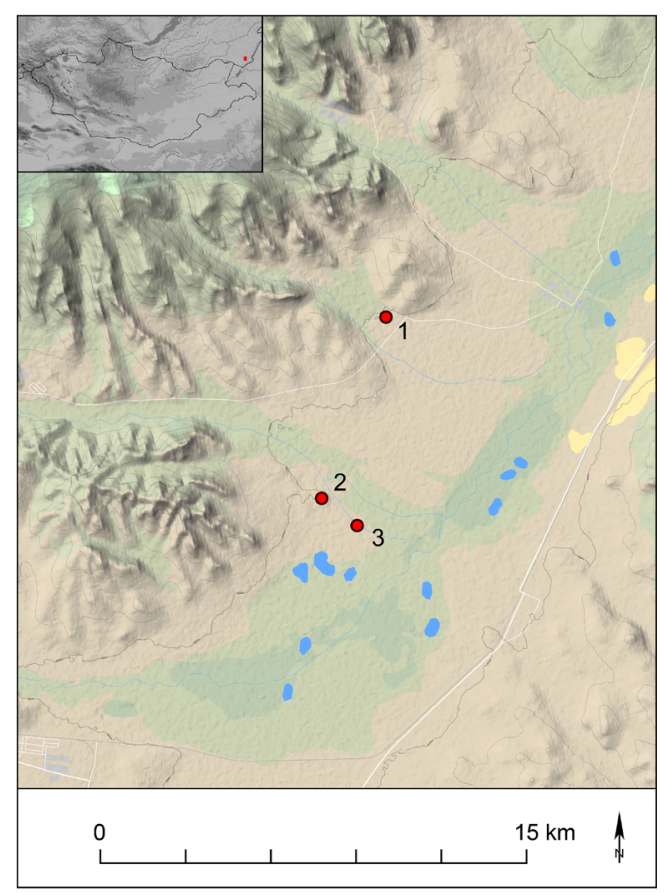

Fig. 9 Map of Khirkhira (3) also showing the locations of Alestur (1) and Okoshki (2) (graphic by Tobias Pfaff, Bonn)

indicate the existence of agriculture in the vicinity of Karakorum during the empire period (Lehmkuhl et al. 2011; Rösch et al. 2010). Finds of plowshares and molding boards within the middle of Karakorum (Kiselev 1965; Reichert 2020) at least point to the fact that the inhabitants had the required tools to undertake agricultural works. Of course, we cannot know who the actual people doing the job were. The Yuan shi reports the establishment of an agricultural colony for the first time in 1283, which had been abandoned and reestablished between this time and 1323 on several occasions (Farquhar 1990: 397). To sum up, we can surely state that people carried out cultivation of crops nearby Karakorum of however restricted scale and under much climatic duress (Boyle 1958: 226-227). And concerning "farming," one should not leave the Orkhon unmentioned, as it delivered a great variety of fishes, and the same is true for Ögiǐ Nuur some $60 \mathrm{~km}$ to the north of the city.

There is abundant evidence for imported goods and longdistance trade. We already mentioned merchants who lived in Karakorum according to literary sources. Archaeological work corroborates this picture. Not only were manufactured ceramics imported from China (Sklebitz 2018) but so were several raw materials for secondary craft processes within the workshops of Karakorum (Reichert 2020). With a concentration on blacksmith operations in these workshops during the early stages of the settlement activities, Karakorum is a likely provider for military equipment. It served as station for the imperial guards and later housed the military colony of the province Lingbei (Barkmann 2002: $16 \mathrm{f}$.). With a proportion of more than $70 \%$, the majority of the imported glazed wares found in the craftsmen quarter of Karakorum stems from kilns of northern China, followed by wares such as the famous blueand-white porcelain from southern China of varying qualities (Sklebitz 2018: 208). With mostly bowls of varying sizes and other tableware identified, only a few items such as miniature vessels hint at religious activities within these houses used for living and working (Sklebitz 2018: 211-213). The overall amount of glazed wares highly speaks for the assumption that Karakorum's population had easy access to these goods, some of them brought there over wide distances of more than $2000 \mathrm{~km}$ as the crow flies. Furthermore, the import of goods can be discerned on the level of botanical macro remains analyzed by Manfred Rösch and his group (Rösch et al. 2010). They could prove that several foreign species must have been brought to Mongolia, with likely origins in Central Asia and China. Especially the distribution of Chinese porcelain wares in the hinterland of Karakorum, proven by surveys in the Orkhon valley, hints to the pervasiveness of imports beyond city limits.

\section{Karakorum and its hinterland}

A city stands in a multifaceted network of relationships with its immediate and wider surroundings. "The importance of long-distance trade for the emergence and development of cities means that we cannot study the city just in relationship to its immediate hinterland. The long-distance trading networks are much larger and much more important for urbanization than often believed, and Central Place Theory cannot do justice to this aspect of urbanism" (Hansen 2008: 74-75). First, the city needs workers from its surroundings, second it needs raw materials that are processed and negotiated in the city, and third, it needs food for the daily needs of the inhabitants. At the same time, the surrounding countryside is the ideal location for buyers of goods produced and traded in the city. Numerous studies have shown that there is no clear separation between the city and its environs and that in several ancient cultures the city and its environs are not linguistically separated, but are described by one and the same term (Marcus and Sabloff 2008a: 22-23). Furthermore, there is no sharp limitation of the hinterland, its extent also depends on timespecific functions and interactions.

We are dependent on written sources for the information on the origin of the labor force. According to this information, people from Han China and the regions south of the Gobi, who also used the building techniques they were familiar with, such as rammed earth walls and ramparts, kang 炕 systems, fired roof tiles, etc., helped to erect the various buildings. After the Xi Xia 西夏 (1038-1226) and Jin 金 (1115-1234) dynasties had disappeared from the political map and afterwards the Song 宋 Dynasty area was conquered step by step by the Mongol army, the huge resources of China were available 
for the Mongol center of power. An inscription from a granite quarry in the upper Orkhon valley, which mentions the origin of workers from today's Hohot, enriches the picture from the written sources with a remarkable detail (Bemmann et al. 2011): specialists in agriculture were also sent from China to Karakorum. Numerous other workers, especially artisans, came from Central Asia, the Black Sea region, or Eastern Europe as prisoners of war to Karakorum, where they carried out commissioned work for the court or the elites (Allsen 1997, 2002). The people entrusted with the administration of the city and the affairs of government, as well as specialists in science and religion, also usually came from the conquered regions, attracted by the new possibilities (de Rachewiltz et al. 1993). So far, there is no evidence that pastoral nomads were settled in Karakorum or that the local population was integrated into the economic system of the city beyond the supply of animals.

The raw materials required for building and road construction come from the surrounding area of the city. Roof tiles, bricks, floor tiles, and building decorations were fired on site, including Buddhist art and devotional objects (Hüttel 2012a; Pohl et al. 2012). The granite used for the column bases and millstones comes from quarries in the upper Orkhon valley. Slate, which was used to cover the kang systems and as road surface in the form of slabs, is also found in several places in the upper Orkhon valley and also directly south of Karakorum in the mountains. Due to the low demand, the quarries were certainly used on a seasonal and occasional basis, i.e., workers from the city went to the surrounding countryside and obtained the necessary materials. Siberian larch, the locally dominant tree species, also served as a building material and is so far the only proven fuel (Pohl et al. 2017: 240-244); fossil fuels were apparently used neither for firing the heating systems nor the ceramic kilns. Charcoal piles, the relics of which would have to be present in large numbers in the surrounding area, have not yet been discovered.

On the one hand, probably all the grey ware produced by pottery wheel was manufactured locally. A Mantou-type kiln for firing grey pottery located directly north of the Buddhist temple within the city area was excavated as early as 2002 without any further details being known (Franken 2005: 148). On the other hand, the majority of the glazed goods and porcelain came to the city as finished products, mainly from production centers south of the Gobi (Sklebitz 2018). Despite the wasteful use of iron in Karakorum's artisan quarter (Reichert 2020), it has not yet been possible to prove the exploitation of local ore deposits or the smelting of ore. This is all the more astonishing as smelting furnaces from the Xiongnu period have been excavated in the Orkhon valley (Pohl et al. 2012; Sasada and Amartuvshin 2014). Cast iron products may all originate from China; Mongolia has so far lacked any evidence of the use of the necessary technology. Gold was already washed from the Mongolian rivers at the time of the first steppe empire of the Xiongnu (Polosmak et al. 2019). This tradition is likely to have continued into the Mongol period, even though scientific analyses are still pending as final proof. Other raw materials necessary for specialized crafts may have come to Karakorum from distant regions, such as mercury or gemstones (see Reichert 2020; also Allsen 2019: 41). At the same time, local raw materials such as birch bark, bones, leather, furs, and wool were used.

Just as for raw materials, a local frame of reference is emerging for the supply of food and livestock on the one hand, as well as an astonishingly wide one on the other. Animals were offered for sale at the city gates, as were cereals. For the animals, however, we do not yet know from which area they were delivered, and isotope analyses should provide a remedy in the coming years. The cereals, however, seem to have been in short supply and had to be imported on a large scale, despite repeated local cultivation attempts. Rashīd al-Dīn reported that already starting under Ögödei, every day 500 wagons each towed by six oxen - loaded with food and drinks arrived in the city (Thackston 1998/1999: 235; Di Cosmo 2014/15: 73). Khubilai Khan successfully used the evident dependence on Chinese grain imports as a means of political pressure in his disputes with Arigh Böke. After no more supply routes reached Karakorum, the latter had to clear Karakorum and abandon it. It is unclear when the transports were resumed. Did this happen only after the disappearance of the anti-YuanSteppe coalition or already in the time of its decline? The news recorded in the Yuan shi gives the impression that in the fourteenth century, grain supply was primarily oriented towards the needs of the garrison troop, whose soldiers were recruited not from the steppe but from China and Korea (Dardess 1972/ 73: 154-159). Even in favorable years, the military colony's crop yield was not sufficient to cover its annual requirements. This was due not only to the fact that alcohol was distilled from grain, which was mentioned several times in the Yuan $s h i$ and which was made a punishable offence, but also to the difficult growing conditions and the natural conditions. An inscription from 1331 mentions the cultivation of grain being threatened by severe drought (Muraoka 2013: 59). In an emergency, the grain reserves kept in storehouses were also used to supply the population: An inscription from 1337 proves that grain from the military stores was sold to the starving and freezing population (Ushine 2013). In 1308 an enormous number of 868,000 refugee households were being issued grain at Karakorum and 2,000,000 ingots cash for cloth and grain were to be provided (Dardess 1972/73: 157).

Karakorum is not alone in its dependency on food imports, and at this point we shall only remind you of grain supplies from North Africa to feed Rome or the transport of grain to the newly founded Roman city of Xanten on the Lower Rhine. These two examples are intended to indicate that there is no typical nomadic deficit here, but that this is a 
problem of high population numbers or a difficulty with a poorly developed or economically self-sufficient settlement environment that is unable to produce the required surplus. Aware of this deficit, the Mongols founded Chinqai early on as an agricultural colony and production site and military farmers were settled in various locations (Buell 1993; Shiraishi et al. 2009; Bretschneider 1967: 59-60). Most scholars locate Chinqai close to the Mongolian Altai, but convincing archaeological evidence is still missing. Several towns south of the Gobi had granaries (Fig. 10), the stocks of which could be transported to Karakorum if necessary (Dardess 1972/73). Since Ögödei, a systematically developed route with 37 relay stations has been used for this purpose (Dardess 1972/73: 124; Thackston 1998/1999: 324).

In what kind of network is such an artificially built city like Karakorum integrated, which did not grow organically out of the region and is also located in a previously city-less economic region, where there was no need for a city? As with the supply with food, Karakorum again was placed within differently scaled communication networks. On the one hand, the city itself embodies a hub with various overland routes with relay stations, while on the other, the city was "only" one stop on the seasonal change of residences by the moving court.
Karakorum was connected to the major overland routes via the yam communication system and thus connected to and beyond the borders of the empire. This network of waystations was not only used for the transmission of news but was also used by embassies and merchants. The costs of transport were at least up to a certain degree overrode by heavy political inducements. Khans are reported to have paid overmarket prices and actively supported merchant bonds financially to attract trade to Karakorum (see Favereau 2018). By 1260 , tax and booty had reached the treasure houses of Karakorum along these supply arteries and contributed significantly to the prosperity of the city and its attractiveness for merchants. This steady and strong influx of people, goods, and treasures may have stunted after the relocation of the capital to today's Beijing. Karakorum then became an outpost, an island far away in the steppes and was fed and highly subsidized by the imperial center in northern China to keep the steppe region under control and because of its high symbolic value. It was a tribute to the birthplace of the dynasty (Cleaves 1952: 31). One would expect that post-1268, elites, merchants, and artisans moved to the new capital, Dadu, and that with that transformation the financial power and economic resources of Karakorum crumbled away. However, no significant decline in quality goods and handicraft activities can

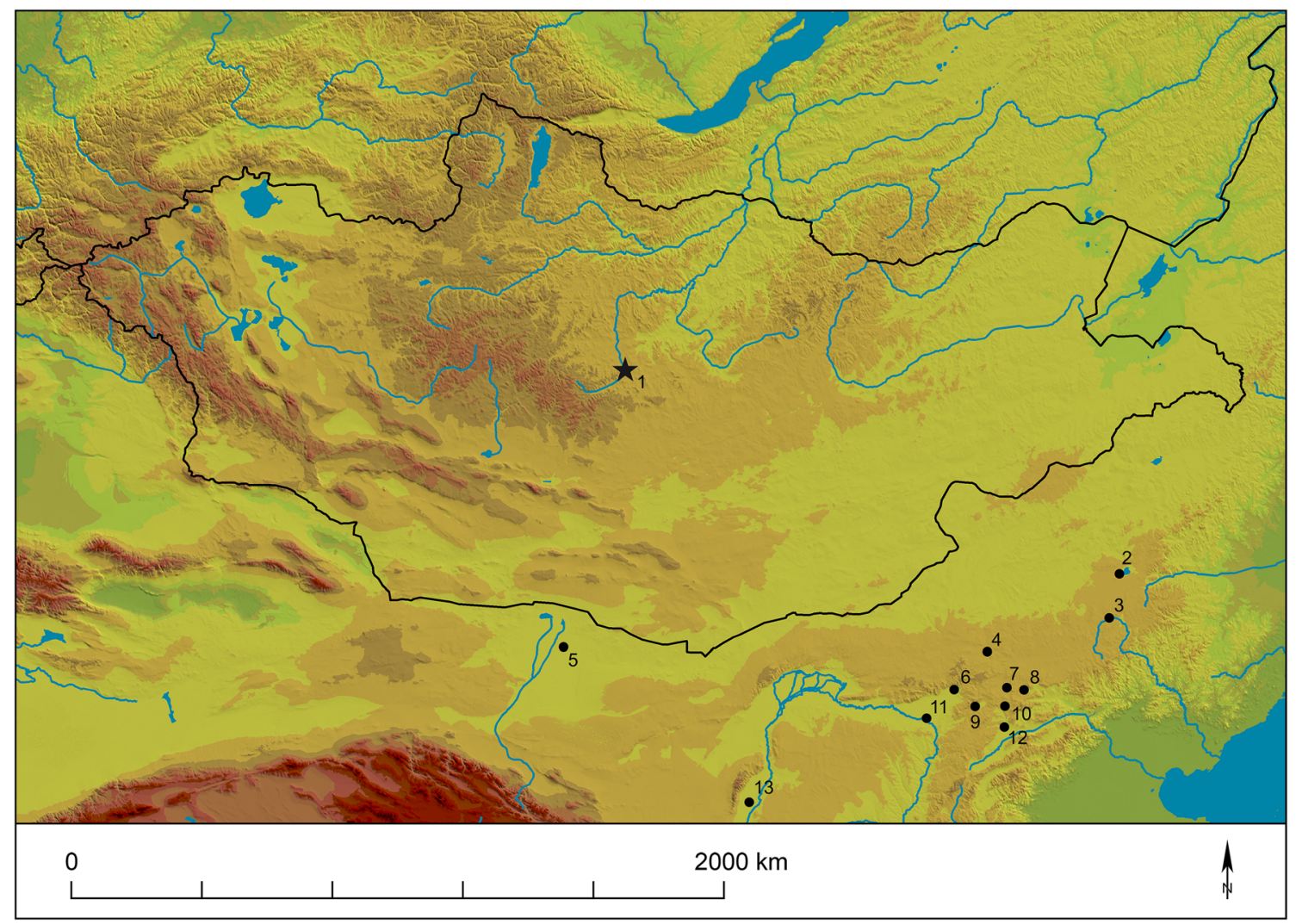

Fig. 10 Map showing supply stations of Karakorum located south of the Gobi (after Dardess 1972/73): 1. Karakorum; 2. Yingchang; 3. Shangdu; 4. Jingzhou; 5. Etzina; 6. Fengzhou; 7. Jining; 8. Xinghe; 9. Pingdi; 10.
Yunnei; 11. Dongsheng; 12. Datong; 13. Ningxia (graphic by Tobias Pfaff, location of sites by Bryan K. Miller, Michigan) 
yet be demonstrated by the small-scale excavations in the city center (Reichert 2020). The statement that the emperor had Karakorum enlarged in 1299 (Yuan shi: 20, 426) also does not fit into the picture of a city in decline.

In addition, the city was integrated through the itinerant movements of the "horde" mobile court into a network of residences which, depending on the preferences of the respective ruler, may have had different stations and may have resulted in the rise and fall of individual sites as a result of the inflow or outflow of labor and specialists. The first Mongol rulers only stayed temporarily in Karakorum and then travelled on to the next residence. This was apparently merely the case during the existence of the "Yeke Mongol Ulus" from 1206 to 1260 . The various residences were mainly located by Boyle and the statements were refined from an archaeological point of view by Shiraishi (Boyle 1974a; Shiraishi 2004). Through the evaluation of aerial photographs and detailed surveys, further contemporary sites with permanent architecture have been added in recent years that can be dated back to the Mongol Empire period on the basis of surface finds. However, their function is largely unclear (Fig. 11). It is striking that so far all facilities have a different layout, and so it is not possible to deduce specific functions. At best, their significance can be inferred from the find material, such as glazed roof tiles covering the more important buildings. One of the sites, Zhargalantyn Shiliīn Balgas (Tsambagarav et al. 2017), was possibly a station on the important southeastern route to

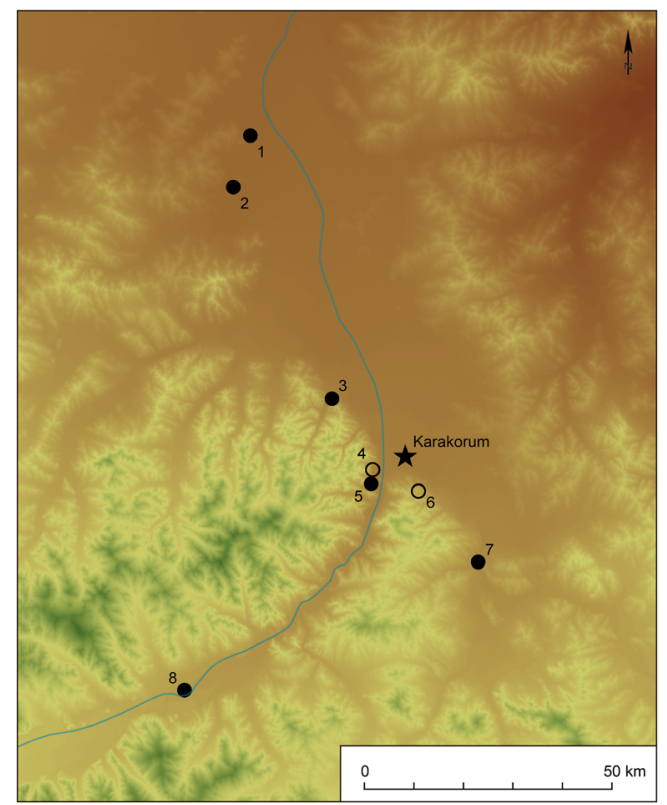

Fig. 11 Locations of residences and settlements with fixed buildings of the Mongol empire period in the Orkhon valley: 1. MOR-82; 2. Doityn Balgas; 3. Bayan gol, 4. OOR-100 (?); 5. Baga Narī̌n Am; 6. Zachyn Bulag (?); 7. Zhargalantyn Shiliı̌n Balgas; 8 . OOR-60 (graphic by Tobias Pfaff, Bonn)
China. As it appears so far, none of the other known permanently populated places - Khar Khul Khaany, Avraga, Bars Khot, Khirkhira, Kondui - is integrated into such a network of seasonally-used residences.

\section{Karakorum and steppe urbanism - A conclusion}

In order to give greater context to Karakorum, we ask how typical are the construction, planning, and use of the city as compared to other documented examples of urban places on the Mongolian Plateau. An almost universal characteristic is the establishment of cities on an open verdant site separate from previous settlements. As far as can be assessed from other investigations, this applies to all large cities, residences, and permanent settlements of the Mongols and apparently also to cities of the Uyghur. Only for the Khitan has it been proven several times that they repaired and extended places erected by the Uyghurs, as in Chin Tolgor̆, Khermen Denzh, and Chilen Balgas. However, the Khitan came from northeast China as invaders to the Mongolian steppe and therefore pursued a different strategy for establishing permanent centers. This means that when steppe regimes founded a city, they purposefully broke away from the specific spots of cities belonging to previous empires, even if the city was founded within the same greater valley of previous establishments. This was done in order to herald the establishment of a completely new empire. Another characteristic, which has already been implicitly stated but which is worth underlining, is that all these urban places or fixed settlements quickly declined after the overarching political system vanished. They did not survive independently. Urbanism was not sustainably carried on by the remaining inhabitants or new arrivals. Karakorum fits into this picture of city foundations without urbanization, in the meaning that the population moves from the steppes to the urban area.

These observations lead us to our initial questions of whether we can discern different trajectories in urbanization within pastoral and sedentary societies, or if there even is urbanization as such. Regarding the latter question, we argue that there is no transformation of a society from a steppe to an urban one. This transient nature of urban sites is not even particular to pastoralist societies. Larger settlements of the Iron Age in Western Europe, attributed urban status by some scholars, show similar developments within sedentary, agrarian-based societies. As to whether we can discern different trajectories in urbanization, we must change the question, since we can no longer compare urbanization but only urbanism. To answer, we would need to identify specific "steppe" characteristics of urbanism. Concerning Karakorum, a discussion employing the list of attributes compiled by Smith would not allow for a strict differentiation in structural traits between the city in the steppe and other urban sites within sedentary 
societies. This observation is not particularly surprising since the discussion also showed that skilled specialists from urbanized, sedentary areas were specifically brought to Karakorum to erect the city and the appeal for the rulers to establish a city was informed by existing locales.

What, then, makes Karakorum special? The investment in large ritual and political buildings, such as the "Pavilion of the Rising Yuan" and the magnificent palace area, as well as the multitude of inscribed stone stelae, which all date from the first half of the fourteenth century (Matsuda and Ochir 2013), occur only at Karakorum. In addition to having structures that are particular only to this capital city, the built environments of Karakorum combine architectural elements from different cultural traditions, elevate them to a far greater size than equivalent structures elsewhere, and exhibit a far greater thickness of settlement layers and refuse material - all of which make Karakorum stand out among permanent settlements of the same time such that even without written documents one would assume the capital of the Mongols to be here.

The analysis of the environs shows impressively that the usual criteria and dimensions for a city-hinterland relationship have been set aside. The city of Karakorum lived beyond its means. A hinterland that can encompass the entire empire for individual needs and the integration of the city into extensive networks are characteristics of an imperial city. The imperial city is "a central place where political, economic, and symbolic power take a material form in urban structures that represent the administrative and ideological institutions of the empire" (Gutiérrez et al. 2015: 535). These cities concentrate vast amounts of wealth from conquered regions and are - in terms of size, number, and quality arenas of ambitious construction programs, and see enormous investments and efforts to achieve monumentality and excellence in every respect (for instance the famous drinking fountain of the palace area). In them, we see a high amount of urban planning that incorporates significant geometries that celebrate the new political order (Gutiérrez et al. 2015: 538), and they show a cosmopolitan assemblage of people in every respect, and serve the ideological and religious legitimation of the ruler and his dynasty (for details, see Gutiérrez et al. 2015).

To conclude, with its planned construction ordered by the uppermost ruler, and its tight relation to the history of the overarching rule from its beginning to its end, Karakorum can be positively identified as a "political city," the genesis and growth of which is driven by political incentives and not by society (Smith 2016: 165).

Acknowledgments Open Access funding enabled and organized by Projekt DEAL. The authors would like to thank Sven Linzen, IPHT Jena for Fig. 2, and the Collaborative Research Center 1167 funded by the German Research Foundation (Deutsche Forschungsgemeinschaft DFG) which provided the framework for this study. This article was written during Jan Bemmann's time as Gerda Henkel Stiftung Member at the Institute for Advanced Study in Princeton. We also thank our Mongolian friends and colleagues from the now again Institute for
Archaeology of the Mongolian Academy of Sciences and the National Museum at Ulaanbaatar, with some of whom we have been working since 1999. This study profited from many fruitful discussions with and hints by Bryan K. Miller and Ernst Pohl. Ishayahu Landa provided Chinese citations and helpful comments with regard to historical intricacies. We thank our two anonymous reviewers for their productive remarks.

\section{Compliance with ethical standards}

Conflict of interest The authors declare that they have no conflict of interest.

Open Access This article is licensed under a Creative Commons Attribution 4.0 International License, which permits use, sharing, adaptation, distribution and reproduction in any medium or format, as long as you give appropriate credit to the original author(s) and the source, provide a link to the Creative Commons licence, and indicate if changes were made. The images or other third party material in this article are included in the article's Creative Commons licence, unless indicated otherwise in a credit line to the material. If material is not included in the article's Creative Commons licence and your intended use is not permitted by statutory regulation or exceeds the permitted use, you will need to obtain permission directly from the copyright holder. To view a copy of this licence, visit http://creativecommons.org/licenses/by/4.0/.

\section{References}

Abramowski, Waltraut. 1976. Die chinesischen Annalen von Ögödei und Güyük: Übersetzung des 2. Kapitels des Yüan-shih. Zentralasiatische Studien 10: 117-168.

Abramowski, Waltraut. 1979. Die chinesischen Annalen des Möngke: Übersetzung des 3. Kapitels des Yüan-shih. Zentralasiatische Studien 13: 7-71.

Allsen, Thomas T. 1996. Spiritual geography and political legitimacy in the eastern steppe. In Ideology and the Formation of Early States, ed. Henri J.M. Claessen and Jarich G. Oosten, 116-135. Leiden: Brill.

Allsen, Thomas T. 1997. Ever closer encounters: The appropriation of culture and the apportionment of peoples in the Mongol empire. Journal of Early Modern History 1 (1): 2-23.

Allsen, Thomas T. 2002. Technician transfers in the Mongolian empire. The Central Eurasian Studies Lectures 2. Bloomington: Indiana University.

Allsen, Thomas T. 2015. Population movements in Mongol Eurasia. In Perspectives on the Global Past. Nomads as Agents of Cultural Change: The Mongols and Their Eurasian Predecessors, ed. Reuven Amitai and Michal Biran, 119-151. Honolulu: University of Hawai'i Press.

Allsen, Thomas T. 2019. The steppe and the sea. Pearls in the Mongol Empire. Philadelphia: University of Pennsylvania Press.

Atwood, Christopher P. 2015. Imperial itinerance and mobile pastoralism: The state and mobility in medieval inner Asia. Inner Asia 17: 293-349.

Barkmann, Udo. 2002. Qara Qorum (Karakorum). Fragmente zur geschichte einer vergessenen Reichshauptstadt. In Helmut Roth and Ulambayar Erdenebat (eds.), Qara Qorum-City (Mongolia) I. Preliminary Report of the Excavations 2000/2001, pp. 7-20. Bonn Contributions to Asian Archaeology, vol. 1. Bonn: Vfgarch-press.

Baumer, Christoph and Mirko Novák (eds.). 2019. Urban Cultures of Central Asia from the Bronze Age to the Karakhanids: Learnings and Conclusions from New Archaeological Investigations and Discoveries. Proceedings of the first international congress on 
central Asian archaeology held at the University of Bern, 4-6 February 2016. Schriften zur Vorderasiatischen Archäologie, vol. 12. Wiesbaden: Harrassowitz.

Bayar, Dovdoin and Vladimir E. Voitov. 2010. Excavation in the Islamic Cemetery of Karakorum. In Jan Bemmann, Ulambayar Erdenebat, and Ernst Pohl (eds.), Mongolian-German Karakorum Expedition 1: Excavations in the Craftsmen Quarter at the Main Road, pp. 289 305. Forschungen zur Archäologie Außereuropäischer Kulturen, vol. 8. Wiesbaden: Reichert.

Becker, Eva. 2012. Karakorum: Fragen zum Stadtplan. Zentralasiatische Studien 41: 43-88.

Bemmann, Jan, Birte Ahrens, Thomas Höllmann, Thomas Kaiser, and Shing Müller. 2011 [2015]. A stone quarry in the hinterland of Karakorum, Mongolia, with evidence of Chinese stonemasons. Journal of Inner Asian Art and Archaeology 6: 101-136.

Bemmann, Jan. 2014. Archäologische Forschungen in der Mongolei: Ein Rückblick auf ein erfolgreiches Kapitel Deutsch-Mongolischer Kooperation. Mongolische Notizen 22: 9-34.

Boyle, John A. 1958. The history of the world-conqueror by 'Ala-ad-din 'Ata-Malik Juvaini. Translated from the text of Mirza Muhammad Qazvini. Manchester: Manchester University Press.

Boyle, John A. 1970. The burial place of the great khan Ögedei. Acta Orientalia 32: 45-50.

Boyle, John A. 1974a. The seasonal residences of the great khan Ögedei. In Gyorgy Hazai (editor), Sprache, Geschichte und Kultur der altaischen Völker: Protokollband der 12. Tagung der Permanent International Altaistic Conference 1969 in Berlin, pp. 145-151. Berlin: Akademie-Verlag.

Boyle, John A. 1974b. The thirteenth-century Mongols' conception of the after life: The evidence of their funerary practices. Mongolian Studies 1: 5-14.

Bretschneider, Emil. 1967. Medieval researchers from eastern Asiatic sources. New York: Barnes \& Noble.

Buell, Paul D. 1993. Činqai. In Igor de Rachewiltz, Hok-Lam Chan, Hsiao Ch'i-ch'ing, and Peter W. Geier (eds.), In the Service of the Khan: Eminent Personalities of the Early Mongol-Yüan Period (1200-1300), pp. 95-111. Asiatische Forschungen, vol. 121. Wiesbaden: Harrassowitz.

Childe, V. Gordon. 1950. The urban revolution. The Town Planning Review 21: 3-17.

Christaller, Walter. 1933. Die Zentralen Orte in Süddeutschland: Eine ökonomisch-geographische Untersuchung über die Gesetzmäßigkeit der Verbreitung und Entwicklung der Siedlungen mit städtischen Funktionen. Jena: Fischer.

Clark, Peter, ed. 2013. The Oxford handbook of cities in world history. Oxford: Oxford University Press.

Cleaves, Francis W. 1952. The Sino-Mongolian inscription of 1346. Harvard Journal of Asiatic Studies 15 (1/2): 1-123.

Cowgill, George L. 2004. Origins and development of urbanism: Archaeological perspectives. Annual Review of Anthropology 33: 525-549.

Dardess, John W. 1972/73. From Mongol empire to Yüan dynasty: Changing forms of imperial rule in Mongolia and Central Asia. Monumenta Serica Journal of Oriental Studies 30: 117-165.

Di Cosmo, Nicola. 2014/15. Why Qara Qorum? Climate and geography in the early Mongol empire. Archivum Eurasiae Medii Aevi 21: 6778.

Dmitriev, Serge Ǐ V. 2011. Karakorum, Otiuken i ranniaia istoriia uı̆gurov. Tiurkologicheskil sbornik 2009-2010: 152-179.

Elichina, Julija I. 2005. Der» »tein des Činggis«. In Kunst- und Ausstellungshalle der Bundesrepublik Deutschland GmbH (editor), Dschingis Khan und seine Erben: Das Weltreich der Mongolen, $\mathrm{p}$. 27. Ausstellungskatalog. München: Hirmer.

Erdenebat, Ulambayar. 2009. Altmongolisches Grabbrauchtum: Archäologisch-historische Untersuchungen zu den mongolischen Grabfunden des 11. bis 17. Jahrhunderts in der Mongolei $(\mathrm{PhD}$
Dissertation). Bonn: Rheinische Friedrich-Wilhelms-Universität. urn:nbn:de:hbz:5-19581.

Erdenebat, Ulambayar. 2011. Archaeological excavation of the Mongolian-German Karakorum expedition in Erdene Zuu. In The international conference on "Erdene-Zuu: Past, present and future”, ed. Takashi Matsukawa and Ayudai Ochir, 190-199. Ulaanbaatar: IISNC.

Farquhar, David M. 1990. The government of China under Mongolian rule: A reference guide. Münchener ostasiatische Studien, vol. 53. Stuttgart: Steiner.

Favereau, Marie. 2018. The Mongol peace and global medieval Eurasia. Comparativ 28 (4): 49-70.

Fletcher, Roland. 2012. Low-density, agrarian-based urbanism: Scale, power, and ecology. In The comparative archaeology of complex societies, ed. Michael E. Smith, 285-320. Cambridge: Cambridge University Press.

Franken, Christina. 2005. Die Brennöfen im Palastbezirk von Karakorum. In Kunst- und Ausstellungshalle der Bundesrepublik Deutschland GmbH (editor), Dschingis Khan und seine Erben: Das Weltreich der Mongolen. Ausstellungskatalog, pp. 147-149. München: Hirmer.

Franken, Christina. 2012/2013. Ausgrabungen der MongolischDeutschen Karakorum-Expedition und der Mongolisch-Deutschen Orchon Expedition in Karakorum und Karabalgasun im Jahr 2012. Zeitschrift für Archäologie Außereuropäischer Kulturen 5: 359 368.

Franken, Christina. 2015. Die "GROSSE HALLE" von Karakorum: Zur archäologischen Untersuchung des ersten buddhistischen Tempels der alten mongolischen Hauptstadt. Forschungen zur Archäologie Außereuropäischer Kulturen, vol. 12. Wiesbaden: Reichert.

Franken, Christina, Ulambayar Erdenebat, and Tsedendambyn Batbayar. 2014. Erste Ergebnisse der Grabungen des Jahres 2013 in Karabalgasun und Karakorum/Mongolei. Zeitschrift für Archäologie Außereuropäischer Kulturen 6: 355-372.

Gaydarska, Bisserka. 2017. Introduction. European prehistory and urban studies. Journal of World Prehistory 30 (3): 177-188.

Geertz, Clifford. 1973 (print 1993). The interpretation of cultures: Selected essays. London: Fontana Press.

Gießauf, Johannes. 2003. Vom Jurtenkarrenplatz zur multikulturellen Metropole: Eine kleine Geschichte Karakorums. In Helmut Bräuer, Gerhard Jaritz, and Käthe Sonnleitner (eds.), Viatori per urbes castraque: Festschrift für Herwig Ebner zum 75. Geburtstag, pp. 201-214. Schriftenreihe des Instituts für Geschichte (Institut für Geschichte der Karl-Franzens-Universität Graz), vol. 14. Graz: Selbstverlag des Instituts für Geschichte.

Gringmuth-Dallmer, Eike. 1999. Methodische Überlegungen zur Erforschung zentraler Orte in ur- und frühgeschichtlicher Zeit. In Sławomir Moździoch (editor), Centrum i zaplecze we wczesnośredniowiecznej Europie Środkowej, pp. 9-20. Spotkania Bytomskie, vol. 3. Wrocław: WERK.

Gutiérrez, Gerardo, Nicola Terrenato, and Adelheid Otto. 2015. Imperial cities. In Norman Yoffee (editor), Early Cities in Comparative Perspective, 4000 BCE-1200 CE, pp. 532-545. The Cambridge World History, vol. 3. Cambridge: Cambridge University press.

Guzman, Gregory G. 2010. European captives and craftsmen among the Mongols, 1231-1255. Historian 72 (1): 122-150. https://doi.org/10. 1111/j.1540-6563.2009.00259.x.

Hansen, Mogens H. 2008. Analyzing cities. In The Ancient City: New perspectives on urbanism in the old and New World, ed. Joyce Marcus and Jeremy A. Sabloff, 67-76. Santa Fe: School for Advanced Research Press.

Honeychurch, William, and Chunag Amartüvshin. 2007. Hinterlands, urban centers, and mobile settings: The "new" Old World archaeology from the Eurasian steppe. Asian Perspectives 46 (1): 36-64. https://doi.org/10.1353/asi.2007.0005. 
Hsiao, Ch'i-ch'ing. 1978. The military establishment of the Yuan dynasty. Harvard east Asian monographs. Vol. 77. Cambridge: Harvard University Press.

Hüttel, Hans-Georg. 2004. Im Palast des Ewigen Friedens: Die mongolisch-deutschen Ausgrabungen im Palastbezirk von Karakorum (Mongolei). In Kommission für Allgemeine und Vergleichende Archäologie Bonn (editor), Expeditionen in vergessene Welten: 25 Jahre archäologische Forschungen in Amerika, Afrika und Asien, pp. 179-208. AVA-Forschungen, vol. 10. Aachen: Linden Soft.

Hüttel, Hans-Georg. 2007. Bericht über die Tätigkeit der Kommission für Allgemeine und Vergleichende Archäologie des Deutschen Archäologischen Instituts in den Jahren 2005-2006: Ausgrabungen des DAI und der Mongolischen Akademie der Wissenschaften in Karakorum 2005-2006. Zeitschrift für Archäologie Außereuropäischer Kulturen 2: 402-412.

Hüttel, Hans-Georg. 2009. Royal palace or Buddhist temple? On search for the Karakorum palace. In Jan Bemmann, Hermann Parzinger, Ernst Pohl, and Damdinsüren Tseveendorzh (eds.), Current Archaeological Research in Mongolia: Papers from the First International Conference on "Archaeological Research in Mongolia" Held in Ulaanbaatar, August 19 $9^{\text {th }}-23 \mathrm{rd}$, 2007, pp. 535-548. Bonn Contributions to Asian Archaeology, vol. 4. Bonn: Vfgarch.Press.

Hüttel, Hans-Georg. 2012a. Berichte für die Jahre 2009-2010 der Projekte der Kommission für Archäologie Außereuropäischer Kulturen des Deutschen Archäologischen Instituts: Die Ausgrabungen der Mongolisch-Deutschen Orchon-Expedition (MONDOrEx). Zeitschrift für Archäologie Außereuropäischer Kulturen 4: 415-419.

Hüttel, Hans-Georg. 2012b. Berichte für die Jahre 2009-2010 der Projekte der Kommission für Archäologie Außereuropäischer Kulturen des Deutschen Archäologischen Instituts: Karakorum, Nordstadt - Grabung 2009. Zeitschrift für Archäologie Außereuropäischer Kulturen 4: 412-415.

Isogai, Ken'ichi, and Yoichi Yajima. 2013a. The Persian inscription of 732 a.H. from Qara-Qorum. In Research on the Extant Inscriptions of the Mongol Empire and the Yuan Dynasty in Mongolia: The Report of the Achievements of the Bichees Project, ed. Koichi Matsuda and Ayudai Ochir, 225-235. Osaka: Osaka International University.

Isogai, Ken'ichi, and Yoichi Yajima. 2013b. The Persian inscription of 742 a.H. from Qara-Qorum. In Research on the Extant Inscriptions of the Mongol Empire and the Yuan Dynasty in Mongolia: The Report of the Achievements of the Bichees Project, ed. Koichi Matsuda and Ayudai Ochir, 237-266. Osaka: Osaka International University.

Jennings, Justin. 2016. Killing civilization: A reassessment of early urbanism and its consequences. Albuquerque: University of New Mexico Press.

Kato, Shimpei. 1997. The Ancient City of Kharakhorum. Beijing: New World Press.

Kegler, K.R. 2015. Deutsche Raumplanung: Das Modell der "zentralen Orte" zwischen NS-Staat und Bundesrepublik. Paderborn: Ferdinand Schöningh.

Kharinskiı̌, Artur V., Tatiana I. Nomokonova, Evgenii V. Kovychev, and Nikolaĭ N. Kradin. 2014. Ostanki Zhivotnykh v Mongol'skikh Zakhoroneniiakh XIII-XIV vv. Mogil'nika Okoshki I (IugoVostochnoe Zabaikal'e). Rossiǔskaia Arkheologiia 2014 (2): 62-75.

Kharinskiĭ, Artur V., Marina P. Rykun, Evgenii V. Kovychev and Nikolay N. Kradin. 2019. Mongol'skiǐ mogil'nik serediny XIII nachala XV vv. Okoshki 1 v Iugo-Vostochnom Zabaĭkal'e: Konstruktivnye i antropologicheskie aspekty. In Sergei G. Bocharov and Airat G. Sitdikov (eds.), Genuézskaia Gazariia i Zolotaia Orda Tom 2, pp. 69-106. Kazan', Kishinev: Institut
Arkheologii im. A. Kh. Khalikova Akademii Nauk Respubliki Tatarstan.

Kimmich, Dorothee. 2017. Ins Ungefähre: Ähnlichkeit und Moderne. Paderborn: Konstanz University Press.

Kiselev, Sergeř V., ed. 1965. Drevnemongol'skie goroda. Moscow: Izdatel'stvo Nauka.

Kiselev, Sergeǐ V., and Nikolă Ia Merpert. 1965. Remeslenno-torgovye kvartaly Kara-Koruma. In Drevnemongol'skie goroda, ed. Sergej V. Kiselev, 173-182. Moscow: Izdatel'stvo Nauka.

Kradin, Nikolaŭ N., ed. 2011. Kidan'skiŭ gorod Chintolgoŭ-balgas. Moscow: Izdatel'stvo "Vostočnaja Literatura" RAN.

Kradin, Nikolaĭ N., ed. 2018. Goroda Srednevekovykh Imperiĭ Dal'nego Vostoka. Moskva: Izdatel'stvo Vostochnoĭ Literatury.

Kradin, Nikolaĭ N., and Svetlana E. Baksheeva. 2018. Goroda Mongol'skoĭ imperii. In Goroda Srednevekovykh Imperiu Dal'nego Vostoka, ed. Nikolay N. Kradin, 281-314. Moskva: Izdatel'stvo Vostochnoĭ Literatury.

Kyzlasov, Leonid R. 2006. Gorodskaia Tsivilizatsiia Sredinnoŭ i Severnoı̆ Azii: Istoricheskie $i$ arkheologicheskie issledovaniia. Moskva: Isdatel'skaia Firma "Vostochnaia Literatura" RAN.

Lech, Klaus (editor). 1968. Al-'Umarī's Darstellung der mongolischen Reiche in seinem Werk Masālik al-abșār fi mamālik al-amșār: Mit Paraphrase und Kommentar. Asiatische Forschungen, vol. 22. Wiesbaden: Harrassowitz.

Lehmkuhl, Frank, Alexander Hilgers, Susanne Fries, Daniela Hülle, Frank Schlütz, Lyudmila Shumilovskikh, Thomas Felauer, and Jens Protze. 2011. Holocene geomorphological processes and soil development as indicator for environmental change around Karakorum, upper Orkhon Valley (Central Mongolia). CATENA 87 (1): 31-44. https://doi.org/10.1016/j.catena.2011.05.005.

Mackens, Sonja, Norbert Klitzsch, Christoph Grützner, and Riccardo Klinger. 2017. Quaternary sediment architecture in the Orkhon Valley (Central Mongolia) inferred from capacitive coupled resistivity and Georadar measurements. Geomorphology 292: 72-84. https://doi.org/10.1016/j.geomorph.2017.05.002.

Marcus, Joyce, and Jeremy A. Sabloff. 2008a. Introduction. In The Ancient City: New perspectives on urbanism in the old and New World, ed. Joyce Marcus and Jeremy A. Sabloff, 3-26. Santa Fe: School for Advanced Research Press.

Marcus, Joyce, and Jeremy A. Sabloff, eds. 2008b. The Ancient City: New perspectives on urbanism in the old and New World. Santa Fe: School for Advanced Research Press.

Matsuda, Koichi, and Ayudai Ochir, eds. 2013. Research on the extant inscriptions of the Mongol empire and the Yuan dynasty in Mongolia: The report of the achievements of the Bichees project. Osaka: Osaka International University.

Mommsen, Hans, Florian Jansen, and Roger Renner. 2001. Geomagnetische Prospektionsmessungen in Karakorum, Mongolei. In Ernst Pohl, Udo Recker, and Claudia Theune (eds.), Archäologisches Zellwerk: Beiträge zur Kulturgeschichte in Europa und Asien. Festschrift für Helmut Roth zum 60. Geburtstag, pp. 7177. Internationale Archäologie Studia honoraria, vol. 16. Rahden/ Westfalen: Marie Leidorf.

Moriyasu, Takao, and Ayudai Ochir. 1999. Provisional report of researches on historical sites and inscriptions in Mongolia from 1996 to 1998. Tokyo: Society of Central Eurasia Studies.

Müller, Ulrich. 2012. Networks of towns - networks of periphery? Some relations between the North European Medieval town and its hinterland. In Sunhild Kleingärtner and Gabriel Zeilinger (eds.), Raumbildung durch Netzwerke? Der Ostseeraum zwischen Wikingerzeit und Spätmittelalter aus archäologischer und geschichtswissenschaftlicher Perspektive. Beiträge des am 28. und 29. Oktober 2010 in Kiel veranstalteten internationalen Workshops, pp. 55-78. Zeitschrift für Archäologie des Mittelalters Beiheft, vol. 23. Bonn: Habelt. 
Muping, Bao. 2015. A multi-storied wooden building in thirteenth century Karakorum: A study on the architectural style of the Xingyuan pavilion. In Koichi Matsuka and Ayudai Ochir (eds.), International Conference on Ten Years of the World Heritage Site - Orkhon Valley Cultural Landscape: Past and Present, pp. 73-82. Ulaanbaatar, Kharkhorin city: IISNC.

Muraoka, Hiroyuki. 2013. Memorial to his honor, Warden Liu of QaraQorum City. In Research on the extant inscriptions of the Mongol empire and the Yuan dynasty in Mongolia: The report of the achievements of the Bichees project, ed. Koichi Matsuka and Ayudai Ochir, 47-60. Osaka: Osaka International University.

Nakoinz, Oliver. 2012. Zentralorte in parallelen Raumstrukturen. In Svend Hansen and Michael Meyer (eds.), Parallele Raumkonzepte: Workshop des Exzellenzclusters Topoi vom 15-17. März 2010, pp. 83-103. Topoi Berlin Studies of the Ancient World, vol. 16. Berlin, New York: de Gruyter.

Pelliot, Paul. 1925. Note sur Karakorum. Journal Asiatique 206: 372 375.

Pèrlėè, Khödöögiĭn. 1961. Mongol ard ulsyn èrt, dundad üeǐn khot suuriny tovchoon. Ulaanbaatar: Ulsyn Khèvlèliĭn Khèrèg Ėrlèkh Khoroo.

Phillips, Eustace D. 1969. The Mongols. London: Thames and Hudson.

Pohl, Ernst. 2005. Amtssiegel. In Kunst- und Ausstellungshalle der Bundesrepublik Deutschland GmbH (editor), Dschingis Khan und seine Erben: Das Weltreich der Mongolen. Ausstellungskatalog, p. 176. München: Hirmer.

Pohl, Ernst. 2009. Interpretation without excavation: Topographic mapping on the territory of the first Mongolian capital Karakorum. In Jan Bemmann, Hermann Parzinger, Ernst Pohl, and Damdinsüren Tseveendorzh (eds.), Current Archaeological Research in Mongolia: Papers from the First International Conference on "Archaeological Research in Mongolia" Held in Ulaanbaatar, August 19th-23rd, 2007, pp. 505-533. Bonn Contributions to Asian Archaeology, vol. 4. Bonn: Vfgarch-press.

Pohl, Ernst. 2010. The excavations in the Chinese craftsmen-quarter of Karakorum (KAR-2) between 2000 and 2005 - Stratigraphy and architecture. In Jan Bemmann, Ulambayar Erdenebat, and Ernst Pohl (eds.), Mongolian-German Karakorum Expedition 1: Excavations in the Craftsmen Quarter at the Main Road, pp. 6313. Forschungen zur Archäologie Außereuropäischer Kulturen, vol. 8. Wiesbaden: Reichert.

Pohl, Ernst, Lkhagvadorj Mönkhbayar, Birte Ahrens, Klaus Frank, Sven Linzen, Alexandra Osinska, Tim Schüler, and Michael Schneider. 2012. Production sites in Karakorum and its environment: A new archaeological project in the Orkhon Valley, Mongolia. The Silk Road 10: 49-65.

Pohl, Ernst, Susanne Reichert, Joachim Block, Karl-Uwe Heußner, and Uwe Treter. 2017. Dendrochronological data from Karakorum and Erdene Zuu, Mongolia. In Jutta Lechterbeck and Elske Fischer (eds.) Kontrapunkte, Festschrift für Manfred Rösch, pp. 231-249. Universitätsforschungen zur Prähistorischen Archäologie, vol. 300. Bonn: Habelt.

Polosmak, Natalia V., Svetlana S. Shatskaya, M. Vladislav Zadorozhnyy, Liudmilla P. Kundo, and Elena V. Karpova. 2019. The Xiongnu gold from Noin-Ula (Mongolia). Archaeology, Ethnology \& Anthropology of Eurasia 47 (1): 83-94. https://doi.org/10.17746/ 1563-0110.2019.47.1.083-094.

Poppe, Nicholas. 1961. Notes on the monument in honor of Möngke khan: The Mongolian inscription. Central Asiatic Journal 6: 14-18.

de Rachewiltz, Igor. 1987. The Chinese inscription of 1279 on the establishment of the Hsüan-Wei Commandery. Rocznik Orientalistyczny 45 (2): 5-13

de Rachewiltz, Igor. 2004. The secret history of the Mongols: A Mongolian epic Chronicle of the Thirteenth Century. Leiden: Brill.

de Rachewiltz, Igor, Hok-Lam Chan, Hsiao Ch'i-ch'ing, and Peter W. Geier (eds.). 1993. In the Service of the Khan: Eminent personalities of the early Mongol-Yüan period (1200-1300). Asiatische Forschungen, vol. 121. Wiesbaden: Harrassowitz.

de Rachewiltz, Igor and Volker Rybatzki. 2010. Introduction to Altaic philology: Turkic, Mongolian, Manchu. Handbook of oriental studies. Section 8 Uralic \& Central Asian Studies, vol. 20. Leiden: Brill.

Radloff, Wilhelm. 1892. Atlas der Alterthümer der Mongolei. St. Petersburg: Buchdruckerei der Akademie der Wissenschaften.

Rashīd al-Dīn, and John A. Boyle. 1971. The successors of Genghis khan: Translated from the Persian of Rashìd al-Dīn by John Andrew Boyle. New York: Columbia University Press.

Reichert, Susanne. 2019. A layered history of Karakorum: Stratigraphy and periodization in the City Center. Bonn contributions to Asian archaeology, vol. 8. Bonn: Vfgarch.Press.

Reichert, Susanne. 2020. Craft production in the Mongol empire: Karakorum and its artisans. Bonn contributions to Asian archaeology, vol. 9. Bonn: Vfgarch.Press.

Reimer, Paula J., Edouard Bard, Bayliss Alex, J. Warren Beck, Paul G. Blackwell, Christopher Bronk Ramsey, David M. Brown, Caitlin E. Buck, R. Lawrence Edwards, Michael Friedrich, Pieter M. Grootes, Thomas P. Guilderson, Haflidi Haflidason, Irka Hajdas, Christine Hatté, Timothy J. Heaton, Alan G. Hogg, Konrad A. Hughen, K. Felix Kaiser, Bernd Kromer, Sturt W. Manning, Ron W. Reimer, David A. Richards, E. Marian Scott, John R. Southon, Christian S.M. Turney, and J. van der Johannes Pflicht. 2013. Selection and treatment of data for radiocarbon calibration: An update to the international calibration (INTCAL) criteria. Radiocarbon 55: 19231945.

Renfrew, Colin. 2008. The city through time and space: Transformations of centrality. In The Ancient City: New perspectives on urbanism in the old and New World, ed. Joyce Marcus and Jeremy A. Sabloff, 29-51. Santa Fe: School for Advanced Research Press.

Rinčen, Yöngsiyebü. 1959. L'inscription Sinomongole de la Stèle en l'Honneur de Möngke Qayan. Central Asiatic Journal 4: 130-142.

Rogers, J. Daniel. 2017. Inner Asian polities and their built environment. Archaeological Research in Asia 11: 1-14. https://doi.org/10.1016/ j.ara.2017.03.002.

Rösch, Manfred, Elske Fischer, Tanja Märkle, and Batbold Oyuntuya. 2010. Medieval plant remains from Karakorum. In Jan Bemmann, Ulambayar Erdenebat, and Ernst Pohl (eds.), Mongolian-German Karakorum Expedition 1: Excavations in the Craftsmen Quarter at the Main Road, pp. 219-249. Forschungen zur Archäologie Außereuropäischer Kulturen, vol. 8. Wiesbaden: Reichert.

Roth, Helmut R. 2002. Topics of Qara Qorum-City (Mongolia). In Helmut Roth and Ulambayar Erdenebat (eds.), Qara Qorum-City (Mongolia) I: Preliminary Report of the Excavations 2000/20012, pp. 23-35. Bonn Contributions to Asian Archaeology, vol. 1. Bonn: vfgarch.press.

Rubruck, William and Peter Jackson. 1990. The Mission of friar William of Rubruck: His journey to the court of the great khan Möngke 1253-1255. Translated by Peter Jackson. London: Hakluyt Society.

Sagaster, Klaus. 1999. Die mongolische Hauptstadt Karakorum. Beiträge zur Allgemeinen und Vergleichenden Archäologie 19: 113-128. Mainz: Philipp von Zabern.

Sagaster, Klaus. 2005. Die chinesisch-mongolische Inschrift von 1346 aus Erdeni Joo. In Kunst- und Ausstellungshalle der Bundesrepublik Deutschland GmbH (editor), Dschingis Khan und seine Erben: Das Weltreich der Mongolen. Ausstellungskatalog, pp. 150-152. München: Hirmer.

Sasada, Tomotaka, and Chunag Amartuvshin. 2014. Iron smelting in the nomadic empire of Xiongnu in ancient Mongolia. ISIJ International 54 (5): 1017-1023. https://doi.org/10.2355/isijinternational.54. 1017.

Shatzman Steinhardt, Nancy. 1988. Imperial architecture along the road to Dadu. Ars Orientalis 18: 59-93.

Shatzman Steinhardt, Nancy. 1990. Chinese Imperial City planning. Honolulu: University of Hawai'i Press. 
Shiraishi, Noriyuki 白石典之. 2002. Mongoru teikokushi no kōkogakuteki $k e n k y \bar{u}$ モンゴル帝国史の考古学的研究 (the archaeological researches on the history of the Mongol empire). Tōkyō: Dōseisha.

Shiraishi, Noriyuki. 2004. Seasonal migrations of the Mongol emperors and the peri-urban area of Kharakhorum. International Journal of Asian Studies 1 (1): 105-119.

Shiraishi, Noriyuki. 2011. Traces of life in the Uighur period found beneath Erdene Zuu monastery. In The international conference on "Erdene-Zuu: Past, present and future", ed. Takashi Matsukawa and Ayudai Ochir, 94-96. Ulaanbaatar: IISNC.

Shiraishi, Noriyuki and Batmunkh Tsogtbaatar. 2009. A preliminary report on the Japanese-Mongolian joint archaeological excavation at Avraga site: the Great Ordu of Chinggis Khan. In Jan Bemmann, Hermann Parzinger, Ernst Pohl, and Damdinsüren Tseveendorzh (eds.), Current Archaeological Research in Mongolia: Papers from the First International Conference on "Archaeological Research in Mongolia" Held in Ulaanbaatar, August 19th-23rd, 2007, pp. 549562. Bonn Contributions to Asian Archaeology, vol. 4. Bonn: vfgarch.press.

Shiraishi, Noriyuki, and Batmunkh Tsogtbaatar. 2013. Ikh KhaĭlantTavan Khaŭlaast: Mongol-Iapony Khamtarsan "Shinè zuun" Tösliun 2012 Ony Khèeriün Shinzhilgèeniĭ Angiun Tailan. Niigata: Niigata University.

Shiraishi, Noriyuki, Hidehiro Sohma, Yuzo Kato, and Altangerel Enkhtör. 2009. A survey of Khünkhüree sites in Mongolia and their significance: A basic study on the "Konggulie granary" of the Yuan dynasty [in Japanese]. Kokuritsu minzokugaku hakubutsukan kenkyu hōkoku 国立民族学博物館研究報告 (Bulletin of the National Museum of Ethnology) 33 (4): 599-638.

Sklebitz, Anne. 2018. Glazed Ceramics from Karakorum: The Distribution and Use of Chinese Ceramics in the Craftsmen Quarter of the Old-Mongolian Capital During the 13th-14th Century A.D. (Inaugural-Dissertation). Bonn: Rheinische Friedrich-Wilhelms-Universität. urn:nbn:de:hbz:5-50054.

Smith, Michael E. 2011. Empirical urban theory for archaeologists. Journal of Archaeological Method and Theory 18 (3): 167-192. https://doi.org/10.1007/s10816-010-9097-5.

Smith, Michael E. 2016. How can archaeologists identify early cities? Definition, types, and attributes. In Eurasia at the Dawn of history: Urbanization and social change, ed. Manuel Fernández-Götz and Dirk Krausse, 153-168. New York: Cambridge University Press.
Smith, Monica L. 2003. Introduction. The social construction of ancient cities. In The Social Construction of Ancient Cities, ed. Monica L. Smith, 1-36. Washington: Smithsonian Books.

Thackston, Wheeler M. 1998/1999. Rashiduddin Fazlullah's Jami'u'ttawarikh compendium of chronicles: A history of the Mongols. Cambridge: Harvard University, Department of Near Eastern Languages and Civilizations.

Tkachev, Valentin N. 2009. Istoriia Mongol'skoǔ Arkhitektury. Moskva: MGSU Izdatel'stvo Assotsiatsii Stroitel'nykh Vuzov.

Tsambagarav, Zhamiangarav, Batsuuri Ankhbaiar, and Tserendorzh Odbaatar. 2017. Zhargalantyn Shiliĭn Balgas. Archive report. https://www.academia.edu/24415343/Jargalantiin_balgas_new

Tsogtbaatar, Batmunkh, Lochin Ishtsèrèn, Toshihiko Miyake, Tomotaka Sasada, Gonchig Batbold, Hiroki Obata, and Noriyuki Shiraishi. 2017. Avargyn balgasaas shinėer oldson darkhny zuukh. Studia Archaeologica 36: 299-308.

Törbat, Tsagaan. 2015. Tavan Tolgoĭn Mongol iazguurtny bulsh. In Khubilaĭ khaan ba tüünil̆g zalgamzhlagchid, ed. Tsègmėdiǔn Tserèndorzh and Sampildondov Chuluun, 182-193. Ulaanbaatar: Tüükh Arkheologiĭn Khüreeelèn.

Turbat, Tsagaan, and Dunburee Batsukh. 2015. Les Tombes de l'élite Gengiskhanide de Tavan Tolgoï. In France-Mongolie: Découvertes Archéologiques Vingt ans de partenariat, ed. PierreHenri Giscard and Tsagaan Turbat, 139-169. Ulaanbaatar: Munkhiin Useg.

Turnbull, Stephen R. 2009. Chinese Walled Cities 221 BC-AD 1644. Fortress, vol. 84. Oxford, New York: Osprey.

Ushine, Yasuhiro. 2013. Two fragments of the inscription on the relief policy in Qara-Qorum. In Research on the extant inscriptions of the Mongol empire and the Yuan dynasty in Mongolia: The report of the achievements of the Bichees project, ed. Koichi Matsuda and Ayudai Ochir, 195-209. Osaka: Osaka International University.

Wasilewski, Jerzy. 1976. Space in nomadic cultures: A spatial analysis of the Mongol yurts. In Altaica Collecta: Berichte und Vorträge der XVII. Permanent International Altaistic Conference 3-8. Juni 1974 in Bonn/Bad Honnef, ed. Walter Heissig, 345-360. Wiesbaden: Harrassowitz.

Wirth, Louis. 1938. Urbanism as a way of life. American Journal of Sociology 44: 1-24.

Yoffee, Norman, ed. 2015. Early cities in comparative perspective, 4000 $B C E-1200 C E$. Cambridge: Cambridge University Press.

Yuan shi 元史. 1976. Song Lian 宋濂 et al. (comp.). Beijing: Zhong hua shu ju. 